\title{
ARGILAS ESPECIAIS: ARGILAS QUIMICAMENTE MODIFICADAS - UMA REVISÃO
}

\author{
Antonio Carlos Vieira Coelho* e Pérsio de Souza Santos \\ Departamento de Engenharia Metalúrgica e de Materiais, Escola Politécnica, Universidade de São Paulo, Av. Prof. Luciano \\ Gualberto, travessa 3, 380, 05508-970 São Paulo - SP, Brasil \\ Helena de Souza Santos \\ Departamento de Física Geral, Instituto de Física, Universidade de São Paulo, CP 66318, 05315-970 São Paulo - SP, Brasil
}

Recebido em 5/4/06; aceito em 17/11/06; publicado na web em 24/7/07

\begin{abstract}
SPECIAL CLAYS: CHEMICALLY MODIFIED CLAYS - A REVIEW. The simultaneous use of the specific values of some structural and chemical properties of clay minerals, such as kaolinite, montmorillonite and talc, allows the development of new properties for these materials, especially in relation to the external and internal microcrystal surfaces. These developments are very diversified for montmorillonite, due to the high specific surface area, expansible basal spacings, easy intercalation inside the 2:1 structural layers and a reversible and high cation exchance capacity. The review presents examples of chemical modifications on kaolins, montmorillonites (bentonites) and talcs.
\end{abstract}

Keywords: special clays; chemically modified clay; surface modified clays.

\section{INTRODUÇÃO}

Um dos grupos das chamadas Argilas Especiais segundo a revista inglesa "Industrial Minerals"1 compreende esmectitas quimicamente modificadas: as esmectitas (principalmente montmorilonitas) ativadas por ácidos e as "organoclays". O conceito de "ativação de montmorilonita", inicialmente restrito à ativação com o uso de ácidos, foi ampliado por O'Driscoll2: tem-se a ativação ácida, a ativação alcalina, ativação "orgânica" ou "neutra" por compostos orgânicos e montmorilonitas naturalmente ativas (terras fuler). Barrer ${ }^{3}$ chamou de ativação a troca do cátion sódio na montmorilonita-Na pelo cátion quaternário de amônio tetra-metil-amônio: essa conceituação foi utilizada neste trabalho, com compostos inorgânicos e orgânicos modificando as propriedades de argilas cauliníticas e esmectíticas, bem como de talcos. Há a proposta australiana ${ }^{4}$ de, em lugar de usar o termo "ativação", ampliá-lo para a expressão mais abrangente "surface treated clays", a qual é aplicável a todas as argilas e argilominerais, abrangendo também as mudanças na superfície dos cristais causadas por transformações térmicas.

\section{ESTRUTURAS CRISTALINAS E MORFOLOGIAS DOS MICROCRISTAIS DE CAULINITA, DE MONTMORILONITA E TALCO}

As estruturas cristalinas e características químicas da caulinita, da montmorilonita e do talco foram descritas por Brindley ${ }^{5}$ e Newman ${ }^{6}$. A composição química da caulinita, expressa pela fórmula de óxidos, é $\mathrm{Al}_{2} \mathrm{O}_{3} \cdot 2 \mathrm{SiO}_{2} \cdot 2 \mathrm{H}_{2} \mathrm{O}$. A fórmula da cela unitária da caulinita, eletricamente neutra, é $\mathrm{Al}_{4} \mathrm{Si}_{4} \mathrm{O}_{10}(\mathrm{OH})_{4}$. A Figura 1 mostra esquematicamente, em vista lateral, duas camadas 1:1 da estrutura da caulinita ${ }^{7}$ : a distância entre dois planos de oxigênios equivalentes em camadas sucessivas é de 7,16 $\AA$ ou $0,716 \mathrm{~nm}$. Como a espessura da camada 1:1 é de 4,37 ̊̊, o espaço entre as camadas tem 2,79 Å de espessura, valor que quase permite a acomodação de moléculas de água intercaladas entre as camadas, moléculas essas com cerca de 2,90 ̊̊ de diâmetro. Como todos os íons da caulinita são incolores, o

*e-mail: acvcoelh@usp.br cristal da caulinita é incolor; portanto, o pó constituído por cristais incolores de caulinita com dimensões da ordem de $2 \mathrm{~m}$ é branco. Essa cor branca do caulim é um dos principais fatores responsáveis por seu grande uso industrial em papel, cerâmica e plásticos, associado às baixas granulometria natural e reatividade química.

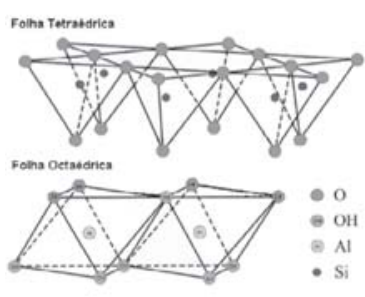

(a)

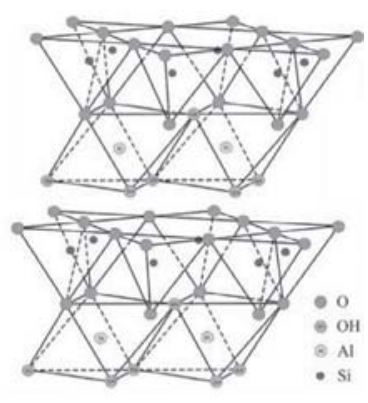

(b)
Figura 1. (a) Representações esquemáticas das folhas tetraédrica e octaédrica, unidades estruturais dos argilomierais; (b) representação esquemática da estrutura da caulinita (argilomineral 1:1). Adaptada da ref. 7

A estrutura de filossilicato orienta preferencialmente o crescimento dos microcristais que têm o formato de placas com perfil hexagonal resultante dos arranjos de oxigênio nas folhas silicato e hidróxido. Essa morfologia pode ser vista na Figura 2, que apresenta cristais lamelares de perfil hexagonal de caulinita. Os microscópios utilizados para a obtenção dessa e das demais micrografias apresentadas foram o de transmissão Philips CM200, operando a $200 \mathrm{kV}$, e o de varredura JEOL modelo JSM840A, operando a $25 \mathrm{kV}$, ambos do Laboratório de Microscopia Eletrônica do Departamento de Física Geral (LME-DFG) do Instituto de Física da USP.

É possível introduzir ou intercalar moléculas eletricamente neutras, orgânicas e/ou inorgânicas, entre as camadas 1:1 e, em consequiência, a distância basal de 7,16 ̊̊aumenta. Contudo, não é usual referir-se ao grupo da caulinita como sendo um grupo que apresenta "basal expansível". Esse mesmo comportamento também é observado em outros argilominerais do grupo da caulinita. 


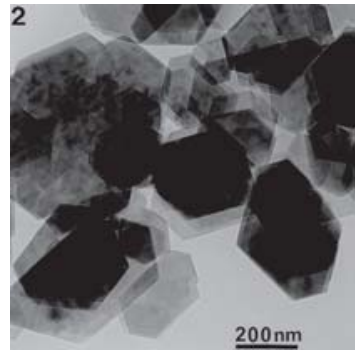

Figura 2. MET de microcristais lamelares de perfil hexagonal de caulinita de caulim do rio Jarí, Amapá

A composição química e a fórmula da cela unitária da montmorilonita "teórica" ou extremo da série é $\left(\mathrm{Al}_{3,33} \mathrm{Mg}_{0,67}\right) \mathrm{Si}_{8} \mathrm{O}_{20}(\mathrm{OH})_{4} \cdot \mathrm{M}^{+1}{ }_{0.67}$, onde $\mathrm{M}^{+1}$ é um cátion monovalente. Essa fórmula mostra que a cela unitária tem carga elétrica negativa devido à substituição isomórfica do $\mathrm{Al}^{3+}$ por $\mathrm{Mg}^{2+}$. $\mathrm{O}$ cátion $\mathrm{M}^{+}$que balanceia a carga negativa é chamado cátion trocável, uma vez que pode ser trocado, de forma reversível, por outros cátions ${ }^{9}$. O teor do cátion trocável, expresso em miliequivalentes do cátion por $100 \mathrm{~g}$ de argila, é chamado CTC - capacidade de troca de cátions. A Figura 3 mostra, lateralmente, duas camadas sucessivas 2:1 de montmorilonita; a distância interplanar basal é da ordem de $15,4 \AA$ A , e a espessura da camada 2:1 é da ordem de $8,97 \AA ̊$ (não confundir essa espessura com a distância interplanar basal, que leva em conta não somente essa espessura, mas também as dimensões dos cátions trocáveis intercalados e a presença de moléculas de água de hidratação dos cátions trocáveis). $\mathrm{O}$ cátion $\mathrm{M}^{+}$ocupa o espaço interplanar das camadas 2:1 e pode estar anidro ou hidratado. Conforme a dimensão do cátion anidro e o número de camadas de moléculas de água coordenadas ao cátion (e, portanto, também intercaladas), pode-se ter valores diferentes da distância interplanar basal. A Figura 4 mostra microcristais de montmorilonita sódica, com o formato de placas muito finas, flexíveis e onduladas, com perfil irregular. A argila (bentonita) é utilizada para diferentes finalidades industriais ${ }^{10}$. A Tabela 1 mostra os valores da distância interplanar basal para montmorilonita saturada por vários cátions e com diferentes teores de água intercalada ${ }^{5}$.

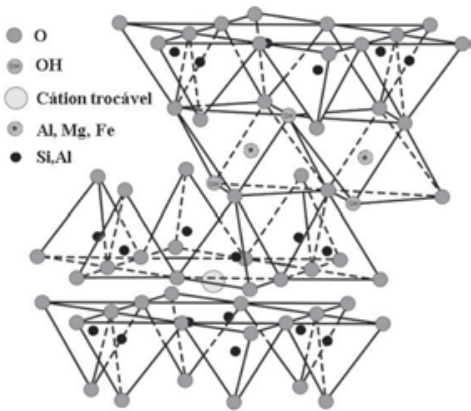

Figura 3. Representação esquemática da estrutura da esmectita (argilomineral 2:1). Adaptada da ref. 7

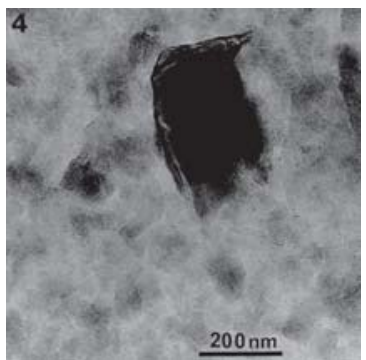

Figura 4. MET de microcristais lamelares de montmorilonita-Na de Landshut, Bavária, Alemanha; são placas de perfil irregular, muito finas, com superfície ondulada e flexível
Tabela 1. Distância interplanar basal de montmorilonita saturada com diversos cátions e diferentes números de moléculas de água ${ }^{5}$

\begin{tabular}{lccccc}
\hline $\begin{array}{l}\text { Número de camadas } \\
\text { de } \mathrm{H}_{2} \mathrm{O} \text { (teórico) }\end{array}$ & \multicolumn{5}{c}{ Distância Iinterplanar } \\
& $\mathrm{Li}^{+}$ & $\mathrm{Na}^{+}$ & $\mathrm{K}^{+}$ & $\mathrm{Mg}^{2+}$ & $\mathrm{Ca}^{2+}$ \\
\hline $0(9,50 \AA)$ & 9,50 & 9,50 & 10,0 & 9,50 & 9,50 \\
$1(12,4 \AA)$ & 12,4 & 12,4 & 12,4 & n.d. & n.d. \\
$2(15,4 \AA)$ & 15,4 & 15,4 & 15,0 & 15,4 & 15,4 \\
$3(18,2 \AA)$ & 19,0 & 19,0 & n.d. & 19,2 & 19,2 \\
$4(21,1 \AA)$ & 22,5 & 22,5 & n.d. & n.d. & n.d. \\
\hline
\end{tabular}

Devido à possibilidade de variar a distância basal, seja pela intercalação moléculas de água, seja pela contração na secagem (com a perda de moléculas de água), a montmorilonita e demais argilominerais do grupo da esmectita são comumente chamados de "argilominerais com basal expansível reversivelmente". Dessa propriedade decorre um grande número de aplicações dos argilominerais do grupo da esmectita, tais como a montmorilonita e a hectorita, em particular para produção de algumas Argilas Especiais.

A montmorilonita propriamente dita, contendo apenas os íons $\mathrm{Si}, \mathrm{Al}, \mathrm{Mg}, \mathrm{O}$ e $\mathrm{H}$, incolores, possui uma cela unitária incolor; se o cátion trocável $\mathrm{M}$ for incolor, como os da Tabela 1, o cristal é incolor, e o pó ou argila (bentonita) dele constituído é branco. Por outro lado, se houver substituições isomórficas na camada 2:1 por cátions coloridos, tais como $\mathrm{Fe}^{3+}, \mathrm{Fe}^{2+}, \mathrm{Cr}^{3+}$ e $\mathrm{Ni}^{2+}$, ou algum desses cátions for o cátion trocável $\mathrm{M}$, a bentonita é colorida. Obviamente, matéria orgânica e minerais associados presentes como impurezas também podem colorir as bentonitas.

A composição química do talco, expressa pela fórmula de óxidos, é $3 \mathrm{MgO} .4 \mathrm{SiO}_{2} \cdot \mathrm{H}_{2} \mathrm{O}$. A fórmula da cela unitária, que é o dobro da fórmula de óxidos, é $\mathrm{Mg}_{6} \mathrm{Si}_{8} \mathrm{O}_{20}(\mathrm{OH})_{4}$. Os cristais de talco são formados pelo empilhamento de camadas 2:1, cada uma sendo constituída por uma folha octaédrica de brucita $\left[\mathrm{Mg}(\mathrm{OH})_{2}\right]$ "ensanduichada" por duas folhas tetraédricas de $\mathrm{SiO}_{2}$. A carga elétrica da cela unitária é neutra. A CTC, muito pequena (1 a 2 meq/100 g) e decorrente apenas das ligações quebradas nas arestas e vértices dos cristais, aumenta com a diminuição do tamanho médio (portanto, com o aumento da área específica) dos cristais. Não havendo cátions intercalados entre as camadas 2:1, a ligação química entre elas é do tipo van der Waals, sendo a força de ligação dirigida perpendicularmente ao plano das camadas $2: 1$, que é o plano 001 da estrutura cristalina do talco. Assim, o cisalhamento paralelamente ao plano 001 é o que consome menor energia: os cristais de talco clivam facilmente, gerando cristais menores, de forma lamelar e com perfil ou contorno irregular, como é mostrado na Figura 5. Desse comportamento dos cristais lamelares de talco decorrem as conhecidas propriedades lubrificantes do talco em pó.

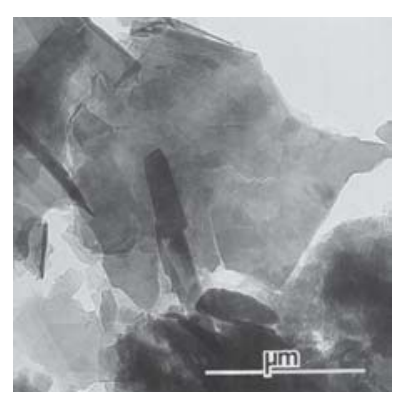

Figura 5. MET de microcristais lamelares de perfil irregular de talco de Itaiacoca, Paraná; algumas placas são muito finas e flexíveis e enrolam, adquirindo aspecto tubular 
Caulins e caulins calcinados, revestidos com compostos orgânicos ("organic coated kaolins"; "organic-clad kaolins")

O primeiro caso a ser considerado compreende aqueles materiais que, tradicionalmente, são fundamentais como cargas ou enchimentos ("fillers") de compósitos cuja matriz é um polímero ou um elastômero, inclusive em tintas, adesivos e materiais semelhantes.

Carga, segundo a norma técnica francesa T30001", é "substância com poder corante fraco e de poder opacificante fraco nos meios de dispersão utilizados e que é incorporada aos polímeros e tintas em geral por razões específicas, econômicas ou técnicas". A definição de compósito, atualmente, costuma ser apresentada de formas muito diferentes. Um livro moderno de Engenharia de Materiais afirma que é possível se encontrar uma definição diferente em cada livro de Ciência e Engenharia de Materiais ${ }^{13}$. Neste artigo, definimos compósito ou material compósito como um material sintético, preparado pela conjugação de dois ou mais materiais, cujas propriedades são nitidamente melhores que aquelas dos materiais componentes ${ }^{14}$.

O segundo caso a ser considerado é aquele quando compostos orgânicos são utilizados para modificar as características superficiais de cargas inorgânicas de uso industrial, seja através da sua adição às cargas antes do processamento para se obter o compósito, seja através de aditivos colocados na formulação no momento do processamento. Modificação de superfície pode ser usada por uma variedade de razões, tais como melhor dispersão das partículas da carga mineral na matriz orgânica; modificação da reologia da dispersão da carga mineral melhoria das propriedades mecânicas. Um exemplo é o caso de compósitos polímero+caulim, descrito a seguir.

A superfície dos cristais de caulinita é constituída por ânions, de um lado $\mathrm{OH}^{-}$e de outro $\mathrm{O}^{2-}$ como mostrado na Figura 1. Isso lhe confere um caráter hidrofílico ou lipofóbico. Assim, a dispersão de caulinita em monômeros ou polímeros não é muito satisfatória, especialmente quanto à individualização dos microcristais de caulinita mostrados. A eficiência de um caulim como carga em relação às propriedades de um compósito depende do grau máximo de dispersão dos microcristais de caulinita na matriz polimérica. Isso somente é possível se os microcristais estão todos individualizados e uniformemente distribuídos na matriz. O processo para obter e manter uma boa dispersão envolve, pelo menos, duas interações superfície-matriz: a matriz, líquida ou fundida, deve molhar a superfície dos microcristais de caulinita; deve haver a estabilização da dispersão ou o retardamento da floculação dos microcristais dispersos após sua defloculação por cisalhamento mecânico das misturas iniciais de caulim+polímero.

Os caulins são constituídos por caulinita e/ou haloisita; têm uma CTC pequena, abaixo de $10 \mathrm{meq} / 100 \mathrm{~g}$ de argila. Nas décadas de 30 e 40 foi observado que: além de trocar reversivelmente cátions inorgânicos, os caulins também trocam cátions orgânicos, tais como cátions de amônio quaternário; também alguns compostos orgânicos polares eram adsorvidos pelos caulins: em ambos os casos, em caulins trocados com cátions orgânicos ou com compostos orgânicos adsorvidos não havia alteração do valor de $7,16 \AA$ da reflexão basal da caulinita; a troca por cátions orgânicos não só era mensurável e de valor igual à CTC da caulinita, como também podia ser observada macroscopicamente se o cátion fosse colorido, como é o caso do azul de metileno (cloreto de metiltionina): caulim branco, em contato com solução de azul metileno, tornavase de cor azul e precipitava. Esses fatos foram interpretados como adsorção dos cátions orgânicos e das moléculas orgânicas, recobrindo faces, vértices e arestas dos microcristais lamelares da caulinita, formando mono ou multicamadas. Esses caulins foram chamados de "organic-clad kaolins". Esses experimentos foram a base para a moderna indústria de cargas, cujos produtos são os "organic coated kaolins" e outras argilas, especialmente talcos, com superfícies modificadas por compostos orgânicos.

Por outro lado, caulins calcinados entre 600 e $900{ }^{\circ} \mathrm{C}$, constituídos por metacaulinita $\left(\mathrm{Al}_{2} \mathrm{O}_{3} \cdot 2 \mathrm{SiO}_{2}\right)$, são usados como cargas revestidas por compostos orgânicos, uma vez que os microcristais possuem apenas ânions $\mathrm{O}^{2-}$ na superfície externa, o que os torna oleofílicos, isto é, perdem o caráter hidrofílico e se tornam mais facilmente dispersáveis em matrizes orgânicas.

Resumindo, os caulins oferecem um conjunto único de propriedades entre as diferentes cargas minerais ("fillers"): boa resistência ao ataque químico por ácidos e álcalis; faixa ampla de granulometrias, desde muito pequena até tamanhos médios (em micrometros); uma faixa ampla de custos de produção que os tornam acessíveis a todos os tipos de compósitos polímero-caulim; uma faixa ampla de interação com polímeros e agentes chamados "surfadores"15 ("surfiers", isto é, modificadores de superfície), de forma a promover a compatibilidade para a produção de compósitos; é produzido com pureza desde moderada até muito alta; a produção industrial dos vários tipos pode ser bastante uniforme. As pesquisas atuais visam produzir caulins de menor granulometria, para adsorver melhor e mais rapidamente os agentes surfadores: como consequiência, produzir caulins revestidos capazes de dispersar mais rápida e completamente, com melhores propriedades reforçadoras (levando a produtos com maior resistência ao impacto, por exemplo), podendo ser utilizados em concentrações maiores nas formulações de compósitos polímero-caulim.

Atualmente, surfação ("surfation") é definida como sendo o resultado de uma interação (geralmente uma reação química) de um composto orgânico com uma carga mineral, como um caulim, para tornar a natureza da superfície das partículas da carga permanentemente organofílica ${ }^{15}$. Prioritariamente, a surfação faz com que o caulim, naturalmente hidrofílico, se torne lipofílico, sendo mais facilmente dispersável de forma completa em meios orgânicos. A escolha do agente surfador depende da matriz polimérica do compósito (material plástico) no qual o caulim revestido irá ser usado e de que tipos de interações são desejadas com o polímero. Silanos (em especial), titanatos e sais de aminas são compostos comerciais usuais para essa finalidade. $O$ caulim revestido com um silano aumenta a resistência ao calor e à deformação com a temperatura de poliamidas (náilon 6,6) e modifica a anisotropia de polímeros parcialmente cristalinos, tais como poliamidas e poliésteres ${ }^{16}$. Em polipropileno, o caulim melhora a resistência aos arranhões ("scratchs"), o que é muito útil em aplicações no interior de automóveis ${ }^{16}$; melhora também propriedades como tensões de ruptura à flexão e à tração em compósitos polímero-caulim ${ }^{17}$.

No processo mais tradicional de transformação da superfície dos cristais de caulinita pela silanização, em meio aquoso, ocorre o mecanismo ${ }^{18-21}$ esquematizado na Figura 6.

Considerese o silano $\mathrm{Y}-\left(\mathrm{CH}_{2}\right)_{\mathrm{n}}-\mathrm{Si}(\mathrm{OR})_{3}$ onde $\mathrm{Y}$ e $\mathrm{R}$ são grupos orgânicos; $\mathrm{R}$ é alquílico e hidrolisável. O silano é hidrolisado na presença de água, acontecendo a reação:

$$
\mathrm{Y}-\left(\mathrm{CH}_{2}\right)_{\mathrm{n}}-\mathrm{Si}(\mathrm{OR})_{3}+3 \mathrm{H}_{2} \mathrm{O} \rightarrow 3 \mathrm{ROH}+\mathrm{Y}-\left(\mathrm{CH}_{2}\right)_{\mathrm{n}}-\mathrm{Si}(\mathrm{OH})_{3}
$$

Os grupos silanóis resultantes dessa hidrólise são normalmente passíveis de formar ligações siloxano com outros grupos silanóis, existentes seja na superfície do argilomineral (presentes em uma das faces da camada 1:1 da caulinita), seja na própria solução.

Pode ocorrer reação de condensação entre os grupos $\mathrm{Si}(\mathrm{OH})$ vizinhos na superfície do argilomineral, aumentado a cobertura de silano e o caráter lipofílico da superfície:

$-\mathrm{Si}(\mathrm{OH})+-\mathrm{Si}(\mathrm{OH}) \rightarrow-\mathrm{Si}-\mathrm{O}-\mathrm{Si}-+\mathrm{H}_{2} \mathrm{O}$ 
Hidrólise

$Y-\left(\mathrm{CH}_{2}\right)_{0}-\mathrm{Si}(\mathrm{OR})_{3} \frac{+\mathrm{H}_{2} \mathrm{O}}{-\mathrm{ROH}} \quad \mathrm{Y}-\left(\mathrm{CH}_{2}\right)_{2}-\mathrm{Si}(\mathrm{OH})_{3}$

\section{Ligação com a superfície}

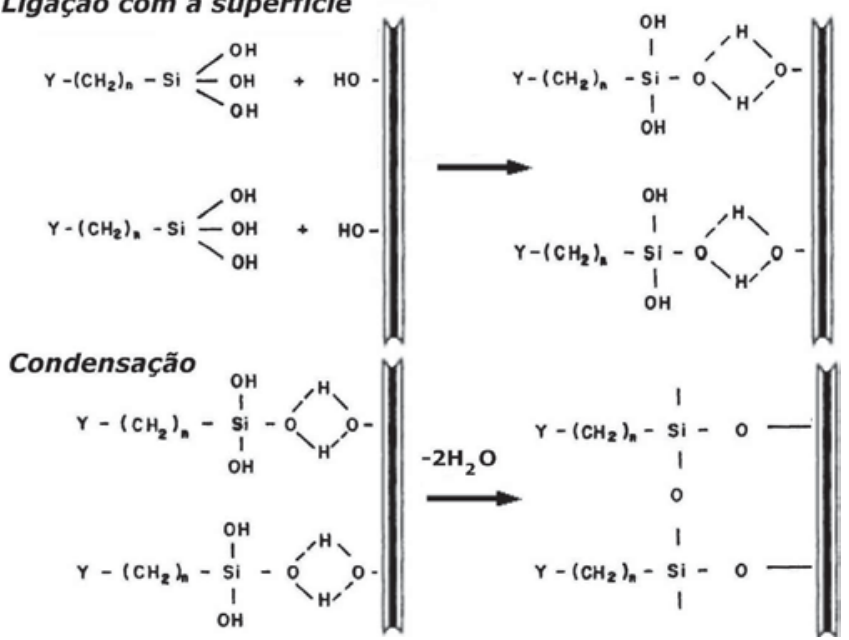

Figura 6. Representação esquemática do mecanismo de transformação da superfície dos cristais de caulinita pela silanização em meio aquoso

A silanização em meio aquoso tem a inconveniência de ser um método no qual a reprodutibilidade não é das mais simples de ser conseguida, pois pode ser difícil controlar a extensão das reações formadoras de grupos siloxano entre as espécies em solução, o que resultaria em coberturas de superfície não reprodutíveis. A alternativa seria a funcionalização envolvendo a formação de ligações covalentes com a superfície via condensação com grupos silanóis ou grupos hidroxilas superficiais na ausência de água. Como essa condição exige a total eliminação da água adsorvida na superfície dos argilominerais, o que é bastante difícil de ser conseguido em vista do caráter fortemente hidrofílico da superfície desses minerais, poucos trabalhos são citados na literatura envolvendo essa forma de funcionalização de superfície ${ }^{20,21}$.

Atualmente, silanos são utilizados para revestir caulins de forma a maximizar as interações e melhorar as propriedades de compósitos caulim-polímero específicos. Exemplos: caulins tratados com metacriloxipropil-silano produzem melhores compósitos com polietileno que caulins tratados com vinil silanos. Caulins tratados com mercaptopropil silanos e aminoalquil-silanos são usados em formulações de elastômeros sem carbono, inclusive substituindo negro-de-fumo. Caulins tratados com alquildimetilclorosilano ou vinil metildicloro-silano são excelentes reforçadores de elastômeros, produzindo compósitos com módulos elásticos muito grandes. Caulins revestidos com silanos são os pigmentos de cor branca utilizados normalmente em tintas a óleo ("paints") e tintas para fins gráficos ou impressão ("inks") 21. A produção de caulins revestidos (também chamados "surface coated kaolins"), considerados como "cargas avançadas" para plásticos nos EUA, foi de $60.000 \mathrm{t}$ em 2000 e o crescimento previsto do setor é de 3,6\% por ano. O mercado de silanos foi estimado em 400 milhões de dólares nesse ano, com um crescimento previsto de 7 a $10 \%$ por ano; parte significativa dessa produção (cerca de 7.000 t) é usada no revestimento não só de caulins, como de outras cargas e pigmentos ${ }^{16}$.

\section{Talco}

Talco vem sendo usado como a melhor carga para polipropileno, sendo utilizado na proporção de $40 \%$ em massa ${ }^{22}$. Dispersa com facilidade, devido à superfície hidrofóbica, conferindo proprieda- des mecânicas muito boas aos compósitos polipropileno-talco. Esses compósitos são usados para componentes interiores e mesmo exteriores de veículos automotivos. Os tratamentos superficiais com compostos orgânicos não melhoram essas propriedades de forma significativa; assim, alguns autores ${ }^{23}$ consideram existir uma grande incógnita em relação à natureza da atividade superficial do talco. Entretanto, deve ser lembrado, observando a estrutura 2:1 da Figura 3 que é a mesma do talco, que ambas as superfícies externas são de $\mathrm{O}^{2-}$ e, portanto, lipofílicas (ou hidrofóbicas). As referências 23 discutem em detalhe a hidrofobicidade da superfície dos microcristais de talco, sob um determinado ponto de vista. Contudo, atualmente, a teoria termodinâmica das superfícies dos argilominerais permite uma diferenciação quantitativa, em termos de energia livre de interação água-superfície, entre hidrofobicidade e hidrofilicidade. A referência 24 trata em detalhe da teoria; ela está resumida na referência 25, a qual trata das propriedades das "Source Clays" da Clay Minerals Society.

\section{Caulim e talco no Brasil}

Atualmente há uma grande produção de caulim no Brasil: o país é o $4^{\circ}$ produtor mundial. Contudo, não há produção de caulins modificados, revestidos com silanos, havendo, no entanto, produção de caulins com baixa granulometria e de caulins calcinados para cargas de borrachas e de plásticos. O Brasil também é grande produtor de talco para plásticos, parte dele silanado, especialmente para uso na indústria automobilística, para toalete e usos farmacêuticos e para cerâmica e papel ${ }^{26}$. As duas grandes regiões produtoras de talco são Brumado (BA) e Ponta Grossa (PR).

\section{Cristais de caulinita e haloisita intercalados com moléculas orgânicas}

Estes casos são, na realidade, apenas itens dentro do que atualmente são chamados de "Compostos de Intercalação". O termo "Intercalação" é usado em Química para descrever a inserção ou introdução reversível de um "convidado" móvel (átomos, moléculas ou íons) dentro de uma estrutura cristalina "hospedeira" que contém um sistema interconectado de vazios estruturais ( > = "lattice sites" ) com dimensões apropriadas. A reação pode ser expressa de forma geral pela Equação:

xConvidado $+{ }_{x}$ Hospedeiro $\rightarrow[\text { Convidado }]_{\mathrm{x}}$ [Hospedeiro $]$

As reações de intercalação são, usualmente, reversíveis e são também transformações pseudomórficas, uma vez que a integridade da estrutura cristalina "hospedeira" é mantida, tanto na reação direta quanto na inversa.

Estruturas cristalinas lamelares eletricamente neutras podem intercalar moléculas neutras. A interação entre moléculas de hospedeiro e convidado é baseada na interação dipolo/dipolo ou em ligação de hidrogênio, esse sendo o caso da caulinita e da haloisita. As informações a seguir valem para ambas as estruturas desses dois argilominerais.

Caulinita é única entre os argilominerais lamelares por possuir camadas assimétricas eletricamente neutras, tendo ânions $\mathrm{OH}^{-}$de um lado e $\mathrm{O}^{2-}$ do outro lado das camadas 1:1 (Figura 2). O caráter polar da camada e os grupos $\mathrm{OH}$ permitem a intercalação de moléculas orgânicas polares, por interação dipolo/dipolo, ou por ligação de hidrogênio. Os exemplos são moléculas pequenas como dimetilsulfóxido (DMSO), hidrazina, uréia, cloreto de sódio, acetato de potássio e amidas, tais como formamida e N-metilformamida; a intercalação desses compostos é reversível e essas moléculas po- 
dem ser trocadas por água. A intercalação das moléculas provoca um aumento da distância interplanar basal de 7,16 ̊̊ da caulinita (e da haloisita), valor específico para cada composto. A velocidade de formação de cada um é também diferente em cada caso e pode servir para a caracterização do argilomineral: esse é o caso da caulinita e da haloisita-7 $\AA$, que podem ser diferenciadas através dessa propriedade, já que através da forma mais simples de caracterização (difração de raios $\mathrm{X}$ do pó de argila sem tratamento prévio) dificilmente podem ser distinguidas uma da outra.

Por outro lado, um grande número de moléculas orgânicas não pode ser intercalado na caulinita, ou por não ter a polaridade adequada, ou por ter dimensões muito grandes. Um procedimento experimental denominado "método do deslocamento" 27 , foi desenvolvido para a intercalação dessas moléculas "inadequadas". Primeiro, há a expansão do espaçamento basal da caulinita por um composto como n-metilformamida (NMF), DMSO ou acetato de potássio; essa expansão atua como uma cunha para permitir a entrada da segunda molécula, "inadequada" por sua polaridade e/ou dimensões, a qual desloca a primeira e forma um híbrido estável hospedeiro-convidado. Assim é possível intercalar uma variedade de monômeros e de polímeros em híbridos caulinita-DMSO e produzir compósitos polímero-caulinita

Uma linha de materiais novos, de baixa "cristalinidade" e elevada área específica, do tipo "ad-cat" (adsorvente-catalisador), vem sendo desenvolvida na Austrália ${ }^{28,29}$ pela decomposição térmica, a diversas temperaturas, de caulinitas intercaladas seja com compostos orgânicos, seja com sais inorgânicos (como o KF), para uso em purificação de efluentes industriais líquidos e gasosos e para a separação de gases.

\section{Caulins com compostos orgânicos intercalados: Brasil}

De nosso conhecimento, não há produção industrial de materiais baseados na intercalação de caulinita ou haloisita; apenas existem excelentes pesquisas acadêmicas, as quais deram origem à expressão "método de deslocamento" 27 . A intercalação repetida e simultânea de acetato de potássio e água em cristais lamelares de caulinita com basal de 7,16 ̊ transforma-os em cristais tubulares ocos de haloisita- $10 \AA^{30}$.

\section{Montmorilonitas ativadas por ácido}

É preciso assinalar que não é só o argilomineral esmectítico montmorilonita propriamente dita que pode ser ativado por tratamento com ácidos inorgânicos: contudo, o fato é que a totalidade da produção industrial usa montmorilonita. Por essa razão, apenas esse argilomineral será considerado neste trabalho. Outro ponto é que a ativação ácida pode ser feita em uma montmorilonita mono ou policatiônica, não importando quais sejam os cátions. Contudo, considerando o fato de que montmorilonita-Ca ou policatiônica, sendo $\mathrm{Ca}^{2+} \mathrm{o}$ cátion trocável predominante, é de ocorrência mais freqüente e com o menor preço, a ativação ácida (com ácido sulfúrico ou clorídrico) é usualmente feita em bentonitas cálcicas.

O tratamento com ácidos serve para três objetivos: dissolver alguma impureza da bentonita (por ex., calcita ou gipsita); substituir o cálcio e outros cátions intercalados por cátions hidroxônio $\mathrm{H}_{3} \mathrm{O}^{+}$; dissolver, nas folhas octaédricas das camadas 2:1 (próximo à superfície dos empilhamentos ou em suas bordas), alguns cátion $\mathrm{Mg}^{2+}, \mathrm{Al}^{3+}, \mathrm{Fe}^{3+}$ ou $\mathrm{Fe}^{2+}$. Alterações morfológicas muito importantes acontecem na estrutura cristalina da montmorilonita durante e após a ativação ácida. Os extremos e as arestas das camadas 2:1 lamelares dos cristais desorientam-se, separam-se e ficam como em um leque aberto (são constituídos por folhas flexíveis e moles de ácido silícico); entretanto, o centro do cristal não se altera e mantém a distância interplanar original. Os cátions trocáveis originais são substituídos por $\mathrm{Al}^{3+} \mathrm{e} \mathrm{H}^{+}$hidratados. Os diâmetros dos poros aumentam e o seu volume interno fica mais facilmente acessível a líquidos e gases. Tanto a área específica dos cristais quanto o seu "poder descorante" ("bleaching performance") aumentam até atingir valores máximos (que são dependentes da argila original) e, depois, ambos diminuem com o tempo de ataque por ácido.

A otimização do poder descorante de uma argila montmorilonítica varia com o óleo e a gordura a ser descorado ou branqueado; geralmente, o máximo desse poder descorante ocorre com o máximo de área específica de ativação ou um pouco abaixo desse valor. A ativação ácida máxima pode aumentar a área específica original de uma esmectita de 3 a 5 vezes, por ex. de 60 a $300 \mathrm{~m}^{2} / \mathrm{g}^{31}$. Até hoje, nenhuma indústria conseguiu desenvolver uma bentonita ativada por ácido cuja capacidade descorante fosse adequada ou ótima para qualquer tipo de óleo, gordura ou cera, comestível ou industrial. Contudo, $\mathrm{Grim}^{32}$, da Ohio State University, USA, sugeriu os seguintes requisitos mínimos para uma "boa" argila esmectítica ativada por ácido para ser usada como agente descorante: área específica na faixa de 120 a $140 \mathrm{~m}^{2} /$ g; pH entre 6,0 e 7,5; porosidade entre 60 e 70\%; ausência de atividade catalítica, no caso de óleos e gorduras comestíveis, para evitar a geração de gostos e cheiros indesejáveis após o descoramento; baixa retenção de óleo na filtração; boa filtrabilidade ou percolação.

Dois pontos importantes devem ser assinalados quanto à área específica das montmorilonitas: a área específica usual de montmorilonitas ativadas por ácidos comerciais, nacionais ou estrangeiras, é da ordem de 150 m²/g; no entanto, empresas como a Süd-Chemie e a Engelhard fabricam argilas ativadas "especiais", com áreas específicas na faixa de 224 a 400 m²/g. Segundo, é comum encontrar na literatura a informação de que as esmectitas podem ter áreas específicas de até $800 \mathrm{~m}^{2} / \mathrm{g}$; esse valor seria a área específica de um cristal com densidade $2,60 \mathrm{~g} / \mathrm{cm}^{3}$ e espessura de $9,6 \mathrm{~nm}$, tendo os lados com 2 × $2 \mathrm{~nm}$; os lados a e $\underline{\mathrm{b}}$ da cela unitária da montmorilonita medem 0,53 e $0,92 \mathrm{~nm}$; portanto, esse cristal teria 8 celas unitárias da montmorilonita e diâmetro da ordem de $0,01 \mu \mathrm{m}$. Não é comum, nem fácil encontrar essas características em bentonitas. Contudo, valores superiores a $400 \mathrm{~m}^{2} / \mathrm{g}$ são obtidos em montmorilonitas tratadas por um processo denominado pilarização ou ponteamento, que será descrito em outro item. Os valores de $750-800 \mathrm{~m}^{2} / \mathrm{g}$ são as áreas específicas máximas calculadas para uma montmorilonita "teórica".

Montmorilonitas ativadas por ácido, na quase totalidade, são utilizadas no refino (branqueamento ou descoramento) de óleos e gorduras comestíveis; óleos, gorduras e ceras industriais; sabões e sabonetes para toalete e usos específicos; de componentes orgânicos de vernizes e tintas; na reciclagem de óleos lubrificantes usados em motores à explosão e para purificação de óleos isolantes para transformadores e turbinas elétricas. Conforme a argila e o material a ser descorado, o teor ponderal de argila está adicionado na faixa entre 0,25 e 5,0\%; as temperaturas utilizadas variam entre 80 até $300{ }^{\circ} \mathrm{C}$ sob vácuo.

Informações relativas à produção e ao consumo mundiais de bentonitas não são facilmente disponíveis na literatura ${ }^{33}$ (embora sejam disponíveis mediante pagamento através de empresas de consultoria internacional); informações não muito recentes relativas à produção mundial de montmorilonitas ativadas apresentam dados de produção de $550.000 \mathrm{t}$ por ano ${ }^{1}$. Os quatro maiores produtores (e respectivos produtos comerciais) são: Süd-Chemie (Tonsil e Tixogel - organofílica); Laporte (Fulmont); Engelhard (Filtrol) e Mizugawa (Mizul); as duas primeiras companhias tem filiais no Brasil, com fábricas em São Paulo.

\section{Montmorilonitas ativadas por ácidos: Brasil}

A referência 34 contém extensa revisão sobre a ativação ácida de argilas esmectíticas brasileiras, bem como sobre os conceitos de "sólido ativo" e "ativação de um sólido". 


\section{Reações coloridas de esmectitas ("NCR Paper")}

Microcristais de montmorilonita sódica, cálcica ou ativada por ácido em contato com uma solução aquosa incolor de cloreto de benzidina trocam $\mathrm{Na}^{+}, \mathrm{Ca}^{2+}$ ou $\mathrm{H}^{+}$pelo cátion benzidina (incolor). Imediatamente, há o desenvolvimento de uma cor azul escura devida à oxidação da benzidina e, em consequiência, toda a montmorilonita adquire a cor azul. Se a ativação ácida foi utilizada também para dissolver cátions ferro na folha octaédrica, é possível obter montmorilonitas ativadas por ácido, com elevada área específica e também com "alvura" ("brightness") muito alta, podendo essa esmectita ser utilizada no "NCR Paper - No Copy Required Paper", ou seja, papel para cópia sem carbono ("carbonless copying paper") 35 .

Esse tipo de papel utiliza um corante incolor (forma leuco = forma incolor), reduzido e cationico, que é adsorvido de uma solução e intercalado entre camadas 2:1 de uma montmorilonita, ativada por ácido, de elevada alvura (acima de 70\%); a leucobase é oxidada e forma um composto estável colorido. Os primeiros papéis sem carbono utilizavam as formas leuco dos corantes violeta cristal (lactona) (LVC) e N-benzoil leuco azul de metileno (N-BLAM) dissolvidas em tolueno. O princípio de funcionamento do papel sem carbono está esquematizado na Figura 7. O desenvolvimento da cópia colorida ocorre da seguinte maneira: a superfície superior do papel onde deverá ser formada a cópia é revestida com uma cobertura de uma montmorilonita ativada por ácido (alvura: 77\% no mínimo; área específica em torno de $290 \mathrm{~m}^{2} / \mathrm{g}$; diâmetro médio dos cristais: $2,5 \mathrm{~m}_{2} \mathrm{O}_{3}: 3,3 \%$ ); essa cobertura (CS) é ligada à superfície por uma cola de amido contendo $\pm 5 \%$ de paligorsquita. A espessura da camada, após secagem, é de 6 a $8 \mathrm{~g} / \mathrm{m}^{2}$. A superfície inferior do papel sobre a qual se escreve (CI) é recoberta com microcápsulas ocas de gelatina ou de poliuretano (com diâmetros na faixa de 1 a $10 \mathrm{~m}$, que contém a solução da leuco-base do corante (LVC ou N-BLAM em tolueno. Sob pressão da ponta de caneta ou lápis, as microcápsulas da camada são perfuradas e/ou esmagadas exatamente no ponto de contato e seu conteúdo é absorvido pela montmorilonita da camada, seguindo-se o desenvolvimento de cor (violeta ou azul, dependendo da leuco-base empregada) de acordo com o percurso seguido pela caneta.

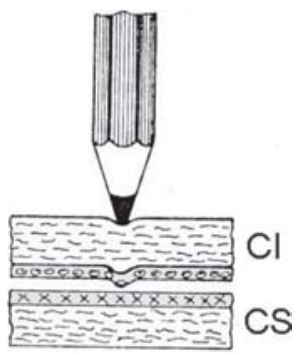

Figura 7. Esquema do primeiro tipo de papel de cópia sem carbono. Adaptado da ref. 35

Modernamente o papel sem carbono é mais sofisticado: usase um segundo corante para assegurar estabilidade frente à luz do primeiro corante que continua a ser o violeta cristal, com cor violeta muito intensa. Este é o segundo grande uso atual das montmorilonitas ativadas por ácido.

\section{"NCR Paper" - Brasil}

Não há ainda produção de argila esmectítica ativada por ácido para uso em papel sem carbono; a argila utilizada no Brasil para esta finalidade é importada.

\section{Bentonitas organofílicas/quaternários de amônio}

No cátion amônio $\left(\mathrm{NH}_{4}^{+}\right)$os hidrogênios podem ser substituídos total ou parcialmente por grupos orgânicos, iguais ou diferentes entre si, que são os compostos quaternários de amônio. Esses cátions podem substituir o sódio de esmectitas ou bentonitas sódicas, produzindo compostos estáveis. O primeiro caso sintetizado a despertar interesse tecnológico foi o cátion tetrametilamônio $\left[\mathrm{N}\left(\mathrm{CH}_{3}\right)_{4}\right]^{+}$, cuja sigla é TMA. A substituição do cátion $\mathrm{Na}^{+}$pelo cátion quaternário de amônio altera o valor da distância interplanar basal de $15,4 \AA$ da montmorilonita ${ }^{3,36}$.

Em 1941, a Baroid Division da National Lead Industries nos USA estabeleceu uma bolsa para pesquisa no Mellon Institute of Industrial Research em Pittisburgh, Pa (atualmente Carnegie Mellon University), intitulada "Novos Usos para Bentonita". O grupo de pesquisadores foi liderado pelo Dr. J. W. Jordan, hoje considerado o pai da tecnologia da bentonitas organofílicas. $\mathrm{O}$ foco da pesquisa estava em torno do fato de que a bentonita sódica é hidrofílica, incha em água e é agente gelificante muito eficiente em muitos sistemas aquosos; entretanto, o inchamento e o poder gelificante não ocorrem em líquidos orgânicos. A grande contribuição de Jordan foi mostrar que bentonitas trocadas com cátions quaternários de amônio - "quats" como foram chamadas - eram organofílicas e excelentes gelificantes em muitos líquidos orgânicos. Jordan ${ }^{37}$ publicou uma tabela, hoje clássica, do inchamento de bentonita de Wyoming - dodecilamônio em 44 líquidos orgânicos mostrando que o inchamento poderia ser de praticamente nulo (não gelifica; ex.: óleo lubrificante $-1,3 \mathrm{~mL} / \mathrm{g}$ ) até gelificante muito eficiente (inchamento de $44 \mathrm{~mL} / \mathrm{g}$ ). Atualmente sabe-se que hectorita organofílica é melhor gelificante que a montmorilonita organofílica produzida com o mesmo quaternário de amônio ${ }^{38}$.

\section{Estrutura cristalina da montmorilonita - alquilamônio}

Hoje é enorme a quantidade de informação sobre a estrutura cristalina dos "quats", devido ao grande número de diferentes ligantes que foram sintetizados com quaternários de amônio para diferentes usos industriais. Vamos como exemplo, a estrutura proposta pela primeira vez por Jordan ${ }^{37}$, decorrente do estudo de cátions quaternário de amônio de cadeia alquilíca, com C1 a C18 átomos de carbono por radical alquídico. $\mathrm{O}$ efeito do número crescente de átomos de carbono no valor da reflexão basal da esmectita está mostrado na Figura 8: observa-se que até 10 átomos de carbono há contração da reflexão basal para o valor constante de 13,6 ̊ e, a partir de 12 átomos, a reflexão basal salta para o valor constante de $17,6 \AA$.

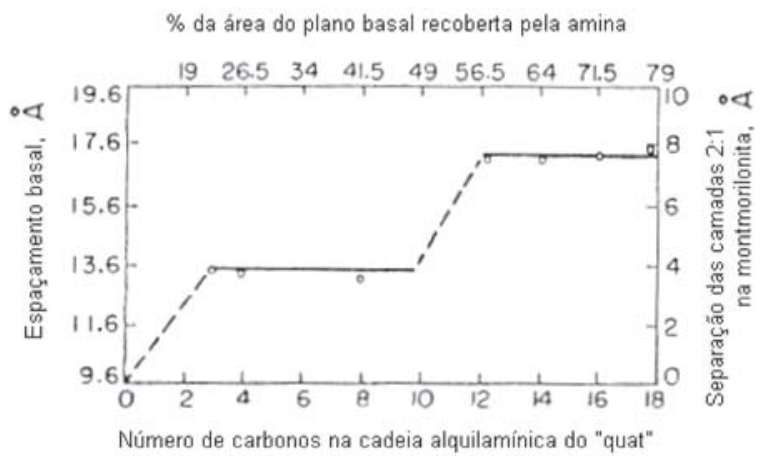

Figura 8. Efeito do número de átomos de carbono na cadeia alquilamínica do quaternário de amônio ("quat") sobre o valor da reflexão basal da montmorilonita organofílica. Adaptado da ref. 39 
A interpretação é a seguinte: nos dois saltos de $4 \AA$ (de 9,6 $\AA$ distância equivalente à espessura da camada 2:1 somada à dimensão do cátion trocável intercalado, sem a presença de água no espaço interlamelar - até $17,6 \AA$ ), o valor 4 A é o diâmetro de van der Waals da cadeia alquílica. Isso significa que as cadeias alquílicas do cátion quaternário de amônio estão estendidas ao longo das faces lamelares das camadas 2:1 e que os planos das cadeias zig-zag de carbonos estão paralelos aos planos das faces de oxigênio da camada 2:1. Essa interpretação é mostrada esquematicamente na Figura 9, onde (a) vale até $\mathrm{C}_{10}$ e (b) de $\mathrm{C}_{12}$ em diante.

\begin{tabular}{|c|c|c|c|}
\hline$\approx$ & 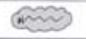 & జజలు & $\alpha$ \\
\hline$\approx$ & $\cong$ & 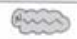 & $\approx$ \\
\hline
\end{tabular}

(a)

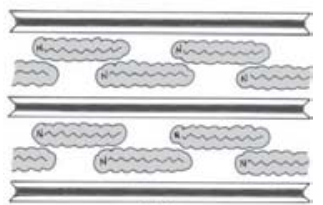

(b)

Figura 9. (a) Esquema da disposição paralela em monocamadas dos cátions "quats" com pequeno número (até 10) de átomos de carbono; (b) esquema da disposição paralela em dupla camada dos cátions "quats" quando o número de átomos de carbono nas cadeias é superior a 12. Adaptado da ref. 39

O Prof. A. Weiss, da Universidade de Heidelberg, Alemanha, propôs um modelo para o caso de concentrações elevadas de "quats" com mais de 12 carbonos e/ou esmectitas com elevada carga elétrica da cela unitária, isto é, com CTC elevada; as moléculas dos "quats" ficariam inclinadas em relação aos planos de oxigênio das camadas 2:1, como mostrado na Figura 10.

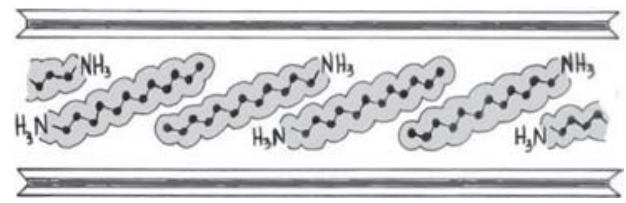

Figura 10. Esquema da disposição inclinada das camadas dos "quats" com muitos átomos de carbono (12 ou mais) em esmectitas com elevado valor de carga negativa das celas unitárias. Adaptado da ref. 39

Esse modelo permite interpretar a intercalação de moléculas de uma substância orgânica após o inchamento; a Figura 11 mostra esse modelo para um quaternário de alquílico e um álcool nalquílico, no qual é mantido o arranjo lamelar bimolecular.

A Figura 12, adaptada de uma proposta feita pelo Prof. G. Lagaly da Universidade de Kiel, Alemanha, na referência 40, é também um desenvolvimento da Figura 10, mostrando como é possível os cátions quaternários de cadeia longa, como $\mathrm{C}_{16}$ ou $\mathrm{C}_{18}$, permitirem também formação de grandes galerias com maiores diâmetros entre as camadas 2:1 com propriedades hidrofóbicas. Lagaly mostrou que, aumentando-se o comprimento, isto é, o número de carbonos da molécula linear alquílica, era possível conseguir que o cátion quaternário de amônio ficasse perpendicular ao plano das camadas 2:1 entre as quais estava intercalado.

Bentonitas organofílicas apresentam grandes valores de inchamento em soluções álcool + hidrocarboneto, bem como uma delaminação completa até que o valor máximo seja atingido. $\mathrm{O}$ valor do inchamento aumenta com o aumento da cadeia do alquilamônio, isto é, de etilamina à dodecilamina, e também com a diminuição do comprimento da cadeia do álcool. O valor máximo do inchamento

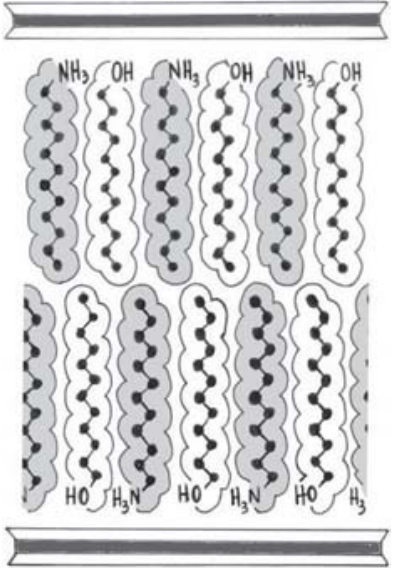

Figura 11. Esquema mostrando como a estrutura da Figura 10 permite a intercalação de moléculas neutras (álcoois, por exemplo) entre moléculas vizinhas de "quats". Essa intercalação de moléculas neutras é feita por adsorção e pode provocar o inchamento da montmorilonita organofílica. Adaptado da ref. 39

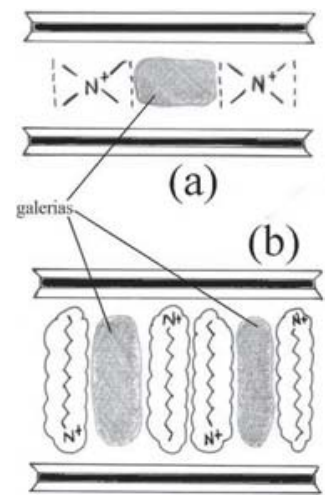

Figura 12. (a) O cátion TMA é simétrico e, quando intercalado entre as camadas esmectíticas, deixa galerias com apenas alguns Angstrons de diâmetro; (b) existem cátions quaternários de amônio cujo formato permite a formação de galerias com maior diâmetro. Adaptada da ref. 40

ocorre para cerca de $10 \%$ de metanol e etanol no sistema bentonita de alquilamônio/álcool/hidrocarboneto ${ }^{39}$. A composição química e as dimensões dos cátions determinam, portanto, a distância interplanar basal da bentonita organofílica, bem como controlam um conjunto amplo de propriedades, especialmente adsortivas e coloidais, que levam ao seu grande uso industrial atual.

O primeiro uso industrial de bentonitas organofílicas foi desenvolvido por Jordan na fabricação de graxas industriais para uso acima de $70{ }^{\circ} \mathrm{C}$, substituindo os sabões de cálcio ou alumínio pelas bentonitas; esses produtos receberam os nomes comerciais de "Bentonas" e "Astrotone"41. A seguir foram usadas em lugar de bentonita sódica em fluidos tixotrópicos contendo líquidos não aquosos para perfuração de poços de petróleo, especialmente no oceano e em camadas salinas. Atualmente, além destas aplicações, são usadas em tintas a óleo, tintas para impressão, cosméticos, adsorventes seletivos para poluentes e biocidas e, mais recentemente, na preparação de "nanocompósitos polímero-bentonita organofílica".

Não existem bons dados estatísticos sobre a produção mundial de bentonitas e hectoritas organofílicas; contudo, as estimativas estão entre 30 e 40 mil t por ano. O maior produtor continua sendo a National Lead Industries (Bentonas), seguidos pela Süd-Chemie (Tixogel), Southern Clay Products (Cloisite e Claytone); a Industrial Mineral Ventures produz hectorita organofílica ${ }^{1,42}$. 


\section{Bentonitas organofílicas:Brasil}

Houve produção de esmectita organofílica no Nordeste utilizando bentonita de Campina Grande, Paraíba. Atualmente há alguns produtores de bentonitas organofílicas em São Paulo, que utilizam bentonitas de São Paulo, da Paraíba e da Argentina. Os compostos quaternários de amônio mais empregados nesses produtos são fabricados no Brasil, especialmente a partir de óleo de coco $\left(\mathrm{C}_{12}, \mathrm{C}_{16}\right)$ e de sebo $\left(\mathrm{C}_{18}\right)$, ambos ricos em ácidos graxos para a produção das alquilaminas com cadeias de $\mathrm{C}_{12}$ a $\mathrm{C}_{18}$.

Nas Universidades de São Paulo e Federal de Campina Grande vêm sendo realizadas, regularmente, pesquisas sobre síntese de bentonitas organofílicas e suas aplicações como adsorventes de poluentes em efluentes industriais, utilizando bentonitas de Boa Vista (Roraima), Campina Grande (Paraíba), Franca (São Paulo), Argentina e dos EUA $^{43-45}$.

\section{Nanocompósitos polímero - esmectita organofílica e "Nanoclays"}

Compósitos de matriz polimérica convencionais ou tradicionais são materiais importantes comercialmente, com aplicações que incluem polímeros e elastômeros carregados com partículas com diâmetros variando de $1 \mathrm{~mm}$ até alguns micrometros. A otimização das propriedades dos compósitos tem sido conseguida através da diminuição de uma ou mais de uma das dimensões das partículas na faixa micrométrica, associada a modificações da sua superfície. Dessa forma, compósitos de matriz polimérica de elevado desempenho mecânico, especialmente utilizando fibras como cargas, têm sido obtidos. No entanto, a melhoria do desempenho mecânico somente pôde ser conseguida em materiais com adição de elevadas porcentagens de cargas (comumente acima de $40 \%)^{46}$. Nas duas últimas décadas vem sendo realizada uma série de estudos no sentido de desenvolver compósitos de matriz polimérica carregados com cargas com dimensões nanométricas, isto é, com dimensões entre 1 e $100 \mathrm{~nm}$. Morfologicamente, o formato da partícula componente da carga pode ser isodiamétrico (cubo ou esfera) ou anisodiamétrico (fibra ou placa); este último caso é o dos argilominerais, cujo formato somente pode ser observado diretamente por MET. Esses compósitos apresentaram não somente propriedades similares àquelas dos compósitos tradicionais de matriz polimérica com adição de quantidades muito menores de carga (comumente em torno de 5\%), como também - e principalmente - apresentaram novas propriedades, impossíveis de serem conseguidas nos compósitos tradicionais: a esses materiais se denomina nanocompósitos ${ }^{46}$.

O termo "nanocompósito" foi inventado ("coined") por Roy e colaboradores, da Pennsylvania State University, USA, que desenvolveram o processo sol-gel. Em 1984, eles modificaram o processo sol-gel para produzir materiais heterogêneos e, desta forma, prepararam diversos materiais nano-heterogêneos di- e multi-fásicos. Segundo esses autores, o termo "nanocompósito" refere-se a "compósitos de mais de uma fase sólida gibbsiana, onde ao menos uma dimensão está na faixa nanométrica, e tipicamente todas as fases estão na faixa de 1 a $20 \mathrm{~nm}{ }^{\text {"47 }}$. Giannelis, da Cornell University, USA, ampliou a faixa de dimensões do componente nanométrico para a faixa de 1 a $100 \mathrm{~nm}^{48}$. Negro de fumo e aerossílica (branco de sílica) são cargas reforçadoras de borracha ou elastômeros, produzindo compósitos de matriz polimérica, cujas propriedades "ativas" são conhecidas desde o início do século XX, sendo conseqüência de suas dimensões nanométricas; em outras palavras, a borracha vulcanizada dos pneus usuais dos automóveis e caminhões, à qual se adiciona negro de fumo, é um nanocompósito já utilizado há muito tempo.
O Grupo de Pesquisa e Desenvolvimento da empresa Toyota ${ }^{49}$ (em Nagakute, Aichi, Japão) demonstrou pela primeira vez em 1970 que as camadas 2:1 de uma esmectita organofílica podem ser dispersas (esfoliadas, buscando individualizar as camadas 2:1, com cerca de $1 \mathrm{~nm}$ de espessura) em um polímero de engenharia, gerando materiais do tipo "nanocompósitos polímero-argila". Esses materiais apresentam valores de propriedades mecânicas que são muito bons, tais como rigidez, resistência ao impacto e à flexão mais elevados que os dos compósitos com as cargas tradicionais, micrométricas. Os efeitos da adição de $5 \%$ de montmorilonita organofílica são equivalentes a $40 \%$ em massa de talco como carga em nailon-6 e polipropileno. A Toyota patenteou o processo de fabricação do nanocompósito, o qual passou a ser utilizado para partes internas de veículos automotivos em todo o mundo. Segundo Eusebi, chefe do Depto. de Pesquisa e Desenvolvimento da General Motors, "os nanocompósitos terão um impacto positivo na indústria automobilística nas próximas duas décadas, especialmente devido ao aumento da estabilidade térmica" ${ }^{16}$. Esse campo de nanocompósitos polímeros-montmorilonitas organofílicas ou híbridos argilas-polímeros tem, portanto, um futuro extremamente promissor.

O termo "nanoclay" começou a ser usado com o desenvolvimento dos nanocompósitos polímero-montmorilonita. A definição de "nanoclay" é: uma argila constituída por lamelas com dimensões nanométricas que podem ser modificadas usando-se diferentes compostos químicos para obter complexos argila-composto orgânico compatíveis com monômeros e polímeros orgânicos ${ }^{42}$. Montmorilonita, hectorita e laponita têm sido as escolhas para "nanoclays" até o momento. No entanto, caulinita também existe em teores significativos com dimensões nanométricas em caulins e essas frações também têm sido usadas como "nanoclays" ${ }^{50}$. Recentemente, haloisita foi mencionada na literatura como sendo interessante na produção de nanocompósitos com aplicação em embalagens e nas áreas médica e farmacêutica ${ }^{51}$. Vermiculita é mencionada na literatura como sendo promissora para a produção de nanocompósitos ${ }^{52,53}$.

Os métodos de síntese de nanocompósitos polímeromontmorilonita apresentados na literatura ${ }^{49,52,54,59}$ são os seguintes: a) dispersão de montmorilonita organofílica em um solvente (ou mistura de solventes) que também dissolva o polímero. O polímero é intercalado juntamente com o solvente, e o nanocompósito é obtido com a eliminação do solvente; b) intercalação do monômero e polimerização in situ (no interior do espaço interlamelar da montmorilonita organofílica); c) intercalação de polímero fundido, de forma estática ou sob uma tensão de cisalhamento ("melt processing"); d) polimerização utilizando um sistema bifásico (polimerização em emulsão ou em suspensão), no qual a montmorilonita se encontra dispersa em fase aquosa e o monômero que será polimerizado, em uma base orgânica que está dispersa na fase aquosa (nesse caso, a montmorilonita não precisa ser organofílica); e) coagulação (e posterior covulcanização) a partir de uma suspensão contendo um látex polimérico e o argilomineral; f) método sol-gel, que consiste na síntese de argilominerais por meio de tratamento hidrotérmico a partir de géis contendo precursores inorgânicos e compostos orgânicos, incluindo o polímero.

Os principais nanocompósitos polímero-montmorilonita organofílica sintetizados foram com poliamidas (como náilon-6), epóxi, polipropileno e tereftalato-polipropileno, mas um número muito grande de outras matrizes poliméricas também vem sendo estudado $^{52,56,58,59}$. As maiores vantagens desses nanocompósitos em relação aos compósitos tradicionais são: menor densidade e, portanto, possibilidade de fabricação de peças mais leves que aquelas de compósito de matriz polimérica convencional; aumento no 
módulo de elasticidade e no limite de escoamento em relação ao polímero não carregado, alcançando valores similares aos obtidos em compósitos tradicionais feitos com fibras com menor quantidade de carga; o aumento da rigidez é acompanhado de menor diminuição da resistência ao impacto em relação àquela observada em compósitos tradicionais; melhoria acentuada de propriedades de barreira para gases e líquidos; aumento da temperatura de distorção térmica; possuem uma redução da flamabilidade; transparência óptica em alguns casos; aceleração da vulcanização dos elastômeros.

Segundo a literatura ${ }^{46,52,56,58,59}$, dependendo das características de cada componente (silicato em camadas 2:1; cátion orgânico e a matriz polimérica e o método de preparação), três casos extremos, típicos, de compósitos "polímero-argila" podem ser obtidos na interação polímero+argilomineral, conforme a Figura 13.

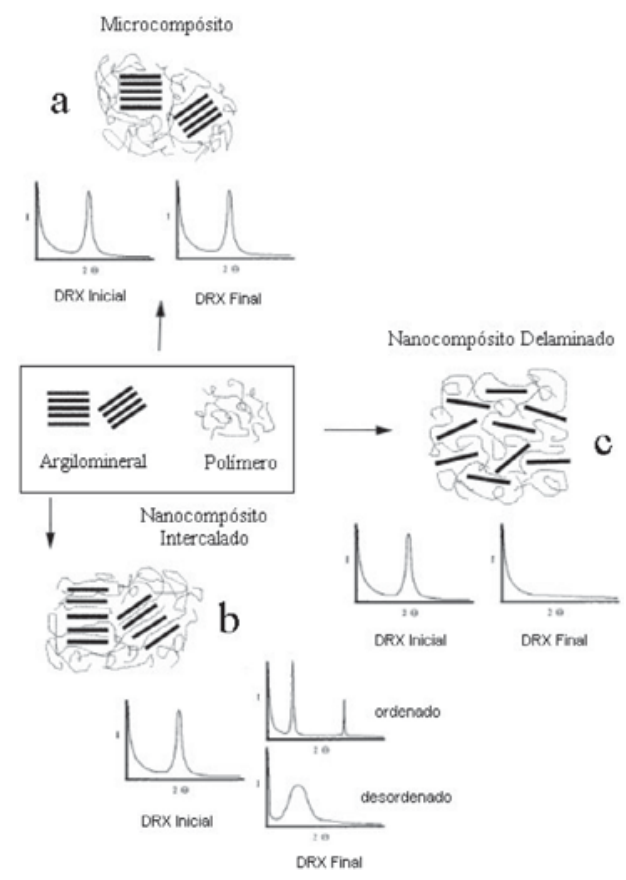

Figura 13. Representação esquemática dos três casos extremos, típicos, de compósitos "polímero-argila" que podem ser obtidos na interação polímero+argilomineral

Quando o polímero é incapaz de intercalar entre as camadas 2:1 ou 1:1 do argilomineral, há a formação de um compósito pela separação entre a fase polimérica e a argila organofílica (Figura 13a). Esse compósito, também chamado de microcompósito, apresenta as mesmas propriedades de compósitos tradicionais ou convencionais, carregados, por exemplo, com talco, caulim e bentonita$\mathrm{Na}$. Tais materiais não podem ser considerados nanocompósitos. $\mathrm{O}$ segundo tipo de compósitos, neste caso realmente nanocompósitos, existe quando cadeias poliméricas estão intercaladas entre as camadas 2:1, mas a delaminação ainda não é completa, existindo "pacotes" de camadas 2:1 intercaladas com cátions orgânicos e/ou polímeros, envolvidos por polímeros: é o "nanocompósito intercalado", Figura 13b. Como os "pacotes" de camadas 2:1 intercaladas podem variar em número e espessura, portanto, conforme o método de preparação, pode-se ter um grande número de nanocompósitos preparados com as mesmas proporções de matérias-primas, porém com propriedades variando dentro de faixas amplas de valores.

O terceiro caso é outro caso extremo, pois ocorre quando todas as camadas 2:1 estão dispersas completamente em uma matriz polimérica, Figura 13c. É o "nanocompósito delaminado".
A difração de raios $\mathrm{X}$ identifica os dois primeiros tipos; o terceiro (nanocompósito delaminado) não apresenta picos na DRX e somente é caracterizado indiretamente, pela variação de suas propriedades, e diretamente, por meio do exame por MET de cortes ultrafinos.

É importante que os pesquisadores que trabalham com nanocompósitos tenham claro qual é o tipo de material que está sendo obtido. Idealmente, deve-se tentar promover a separação completa e a individualização das camadas 2:1, somente então sendo atingido não só o valor máximo do fator de forma ("aspect ratio" = fator de forma: quociente diâmetro/espessura das camadas 2:1), como também a certeza das dimensões nanométricas das partículas da carga ou reforçamento. Entretanto, nos materiais nanocompósitos produzidos atualmente, tanto em laboratório quanto industrialmente, o que se encontra na realidade são proporções relativas distintas desses três tipos: naqueles onde há sucesso na intercalação do monômero ou do polímero encontram-se, predominantemente, frações intercaladas e delaminadas, e nada (ou quase nada) de material não intercalado nem delaminado (microcompósito) ${ }^{58}$. Enquanto as partículas do argilomineral continuarem como agregado de lamelas, apresentando espessuras ao longo de $\mathrm{d}_{001}$ maiores que $100 \mathrm{~nm}$, ainda teremos polímeros convencionais ou tradicionais reforçados com bentonitas organofílicas, podendo não acontecer o desenvolvimento de propriedades específicas de nanocompósitos. As propriedades finais do material serão resultantes das estruturas presentes e de suas porcentagens relativas.

A utilização de nanocompósitos de argilominerais em matriz polimérica é extremamente promissora, mas ainda se encontra em início. Além de aspectos tecnológicos que merecem um melhor detalhamento, questões fundamentais aguardam discussão ou resposta, tais como: Qual é o modelo ou mecanismo de entrada ou de intercalação dos monômeros ou dos polímeros líquidos entre as camadas das montmorilonitas organofílicas? Existem modelos a serem discutidos ${ }^{60}$ ? Qual é o limite máximo de quantidade de intercalação do monômero ou polímero? O que realmente ocorre nas interfaces entre as lamelas de argilominerais e a matriz polimérica? Como se comparam os valores dos diferentes coeficientes de difusão das moléculas do polímero dentro das camadas 2:1 e no polímero puro ou não-carregado? Quais são os valores máximos de propriedades mecânicas que podem ser obtidos (não conhecidos, porque não se sabem os valores dessas propriedades nas lamelas dos argilominerais)? Todos esses tópicos justificam o crescimento exponencial que vem sendo experimentado por esse tema de pesquisa na última década ${ }^{46}$, bem como justificam a necessidade de revisão crítica dos conhecimentos mais recentes sobre os nanocompósitos polímeros-argilominerais, para que sejam bastante precisas a conceituação e a caracterização estrutural do nanocompósito polímero-esmectita, tal como feito por Lagaly no final dos anos $90^{61}$.

\section{Pilarização ("pillaring"; "pontage”)}

O conceito de pilarizar um sólido lamelar como um meio de formar derivados microporosos (isto é, com diâmetro de poros menor que 2,0 nm) foi demonstrado em 1955 por Barrer, do Imperial College of Science and Technology, Londres. Ele substituiu o $\mathrm{Na}^{+}$em montmorilonitas-Na por $\left[\mathrm{N}\left(\mathrm{CH}_{3}\right)_{4}\right]^{+}$, sintetizando a montmorilonita-TMA com galerias entre os cátions quaternários de amônio ${ }^{3}$. Posteriormente, Weiss ${ }^{39}$ e Lagaly ${ }^{40}$ mostraram como é possível controlar o diâmetro das galerias com o número de carbonos da cadeia alquílica do "quat".

Na Figura 12(b) mostrou-se a formação de galerias entre as camadas 2:1 de montmorilonita por cátions quaternários de alquilamônio com mais de 12 carbonos na cadeia. A altura da galeria é da ordem de 0,9/1,0 nm, facilmente observável por difração 
de raios X. A distância entre as moléculas age como suporte ou "pilares", isto é, o diâmetro das galerias é da ordem de 1,3/1,5 nm. Portanto, as montmorilonitas com quaternários de amônio alquílicos com cadeia com mais de 12 carbonos são materiais microporosos. Contudo, aquecendo-se esses materiais entre 200 e $500{ }^{\circ} \mathrm{C}$ em atmosfera oxidante, o quaternário é decomposto; a estrutura esmectítica 2:1 contrai e volta para o valor de 9,6 ̊̊ da forma anidra. Em conclusão: essas galerias não são estáveis.

Em 1977, Brindley, da Pensiylvania State University, USA, teve a idéia de intercalar na montmorilonita de Wyoming um cátion inorgânico com carga elevada que asseguraria, de um lado, as dimensões do cátion e a altura das galerias e, por outro, maior distância de separação ou o maior diâmetro das galerias ${ }^{62}$. Para isso escolheu o cátion poli-hidroxialumínio denominado $\mathrm{Al}_{13}$, cuja fórmula é $\left[\mathrm{Al}_{13} \mathrm{O}_{4}(\mathrm{OH})_{24}\left(\mathrm{OH}_{2}\right)_{12}\right]^{7+}$. Esse cátion é um íon do tipo Keggin; estruturas de Keggin são compostos aniônicos metal-oxigênio tendo fórmula molecular $\mathrm{XM}_{12} \mathrm{O}_{40}$ onde " $\mathrm{X}$ " é um átomo metálico central coordenado tetraedricamente e ligado a 12 átomos metáli$\cos$ " $\mathrm{M}$ " periféricos coordenados octaedricamente. Considerando apenas os oxigênios da fórmula do cátion $\mathrm{Al}_{13}$, ela se torna $\left(\mathrm{Al}_{13} \mathrm{O}_{40}\right)$. Portanto, o $\mathrm{Al}_{13}$ pode ser considerado com fórmula e estrutura do tipo $\left(\mathrm{Al}_{12} \mathrm{O}_{4}\right)$ de Keggin, como foi feito por Johanson ${ }^{63} \mathrm{em} \mathrm{1960,} \mathrm{o}$ qual estabeleceu a estrutura poliédrica do $\mathrm{Al}_{13}$. A diferença da estrutura do $\mathrm{Al}_{13}$ para a estrutura de um íon de Keggin normal é que um íon de Keggin é policatiônico, enquanto o $\mathrm{Al}_{13}$ contém somente alumínio como cátion.

A solução contendo o cátion $\mathrm{Al}_{13}$ é usualmente preparada a partir da hidrólise alcalina de solução aquosa de cloreto ou de nitrato de alumínio. Os cátions $\mathrm{Al}_{13}$ são intercalados em montmorilonita-Na, de preferência a fração de diâmetro menor que $2 \mu \mathrm{m}$ separada por sedimentação, substituindo por troca de cátions o cátion sódio. A intercalação adequada exige cuidados que são descritos na literatura em trabalhos tais como os de Vieira Coelho et al. ${ }^{64}$. A intercalação do cátion $\mathrm{Al}_{13}$ aumenta a distância interplanar basal anidra da montmorilonita-Na de Wyoming de 9,6 para 18,9 $\AA$; em esmectitas brasileiras a faixa observada foi de $18,15 / 19,8 \AA$.

A análise térmica diferencial de montmorilonita mostra que ela começa a se decompor por desidroxilação a partir de $600{ }^{\circ} \mathrm{C}$; portanto, aquecer uma montmorilonita abaixo de $500{ }^{\circ} \mathrm{C}$ não altera a estrutura cristalina nem a reflexão basal característica de 9,6 ̊̊ da forma anidra. Por outro lado, o cátion $\mathrm{Al}_{13}$ em um sal decompõe-se pelo aquecimento a $400{ }^{\circ} \mathrm{C}$, formando um aglomerado de unidades de $\mathrm{Al}_{2} \mathrm{O}_{3}$. Segundo Pinnavaia, da Michigan State University, USA, na decomposição do $\mathrm{Al}_{13}$ durante o processo de pilarização ocorre a reação química ${ }^{65}$ :

$$
2\left[\mathrm{Al}_{13} \mathrm{O}_{4}(\mathrm{OH})_{24}\left(\mathrm{OH}_{2}\right)_{12}\right]^{7+} \rightarrow 13 \text { " } \mathrm{Al}_{2} \mathrm{O}_{3} \text { " }+14 \mathrm{H}^{+}+65 \mathrm{H}_{2} \mathrm{O}
$$

Pelo aquecimento, os prótons $\mathrm{H}^{+}$liberados neutralizam em parte a carga negativa das camadas 2:1.

Como Brindley e Sempels ${ }^{62}$ mostraram em 1977, do aquecimento de montmorilonita- $\mathrm{Al}_{13}$ a $400{ }^{\circ} \mathrm{C}$ resultava uma montmorilonita- $\mathrm{Al}_{2} \mathrm{O}_{3}$, na qual os aglomerados de $\mathrm{Al}_{2} \mathrm{O}_{3}$ estavam separados, deixando entre si galerias e também separavam, de forma segura e estável tal como pilares de uma ponte, as camadas 2:1. Esse processo foi chamado de "pilarização" e as montmorilonitas pilarizadas costumam ser chamadas pela sigla "PILC".

A estrutura dos pilares de alumina, segundo Pinnavaia ${ }^{66}$, é a de uma coluna de 13 octaedros de alumina coordenados em três camadas. A camada superior do pilar tem um oxigênio em comum com um $\mathrm{SiO}_{4}$ invertido da folha tetraédrica de uma camada 2:1, enquanto a camada inferior do pilar tem dois oxigênios em comum com o $\mathrm{SiO}_{4}$ da folha tetraédrica da camada 2:1 de montmorilonita que está imediatamente abaixo.
A dimensão dos microporos em montmorilonitas intercaladas com $\mathrm{Al}_{13}$ (ao longo do eixo cristalográfico c ) é da ordem de $0,9 \mathrm{~nm}$ (9 Å), medida por DRX. A desidroxilação a $400{ }^{\circ} \mathrm{C}$ produz uma contração da forma $\mathrm{Al}_{13}$ intercalada e a dimensão final depende da argila utilizada: em montmorilonita de Wyoming, a reflexão basal baixou para 18,2/18,5 $\mathrm{\AA}$ e em esmectitas brasileiras baixou para 16,8/18,0 Å. A distância entre os pilares não é mensurável por DRX. Contudo, pela adsorção de moléculas de vários diâmetros, essa distância pode ser avaliada como sendo entre 0,8 a $1,0 \mathrm{~nm}$, podendo chegar a $1,3 / 1,5 \mathrm{~nm}^{31}$.

As áreas específicas de montmorilonitas pilarizadas com $\mathrm{Al}_{13}$ costumam estar entre 200 e $300 \mathrm{~m}^{2} / \mathrm{g}$, podendo chegar a $400 \mathrm{~m}^{2} / \mathrm{g}$. A pilarização também pode ser feita com poli-hidroxicátions ou outros compostos de outros cátions, tais como gálio, cromo, zircônio, ferro, titânio, sílica, nióbio, tântalo, vanádio, cobre, inclusive podendo ser sintetizados compostos formando pilares com óxidos mistos, como por exemplo os de alumínio-gálio ${ }^{64,67,68}$.

Atualmente sabe-se que três requisitos são fundamentais para a formação de compostos por pilarização: a estrutura das galerias deve ser suficientemente resistente para permitir a expansão vertical das galerias, especialmente após a desidroxilação do precursor intercalado e, se possível, da camada 2:1; os pilares devem estar lateralmente separados entre si para permitir acesso inter-pilares por moléculas grandes, a começar com $\mathrm{N}_{2}$; as camadas do hospedeiro devem ser suficientemente rígidas para sustentar qualquer separação lateral desejada para os pilares ${ }^{67,68}$.

O maior do interesse atual em argilas pilarizadas está focalizado na sua utilidade como catalisadores em catálise heterogênea que apresentam seletividade de forma ${ }^{67,68}$. Entretanto, Pinnavaia sugeriu uma aplicação interessante da montmorilonita-Al pilarizada como adsorvente no controle de substâncias tóxicas e efluentes para proteção do meio ambiente ${ }^{69}$; a sugestão está esquematizada na Figura 14. Os compostos tóxicos poluentes dissolvidos são adsorvidos nas galerias da montmorilonita-Al pilarizada, deixando a água purificada. A argila é separada, seca e calcinada abaixo de $500{ }^{\circ} \mathrm{C}$ para destruir o material orgânico adsorvido, regenerando a argila pilarizada e permitindo sua re-utilização.

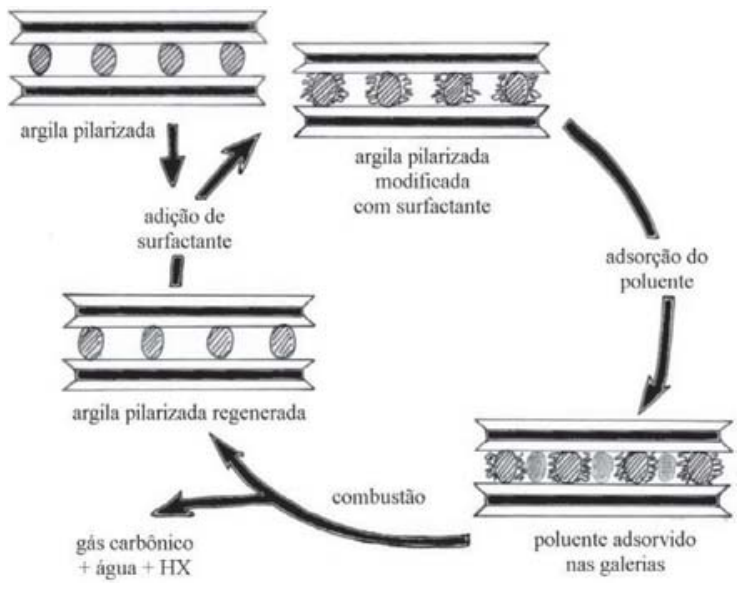

Figura 14. Representação esquemática de sugestão de aplicação de montmorilonita-Al pilarizada (modificada com um surfactante) como adsorvente no controle de substâncias tóxicas e efluentes para proteção do meio ambiente. Adaptada da ref. 69

A nomenclatura sobre pilarização está normatizada pela IUPAC ${ }^{70}$. A pilarização de argilas foi revista por Vieira Coelho e colaboradores em várias publicações ${ }^{64,71}$, inclusive sobre a pilarização de esmectitas brasileiras. Esta revista tem publicado vários artigos sobre pilarização de argilas brasileiras e estrangeiras ${ }^{72}$. 


\section{Argilas como catalisadores}

Em 1936, E. Houdry introduziu na indústria de petróleo do EUA o emprego de argilas como catalisadores: as argilas eram montmorilonitas ativadas por ácido e haloisitas com baixo teor de ferro e eram utilizadas no craqueamento térmico do petróleo. A atividade catalítica era avaliada por um ensaio de laboratório chamado CAT-A em que é medida a conversão de um petróleo leve do Leste do Texas em gasolina. As montmorilonitas ativadas produziam 40 a $45 \%$ de conversão, enquanto as haloisitas apenas 20 a $30 \%$. Por essa razão somente montmorilonitas ativadas por ácido passaram a ser usadas em craqueamento de petróleo.

Em 1938, nos EUA havia uma produção de 470 t por dia de montmorilonita ativada para processar 2 milhões de barris de petróleo por dia. Na época, essa produção de montmorilonita representava $40 \%$ da produção total de catalisadores nos EUA. Essas montmorilonitas ativadas foram utilizadas como catalisadores comerciais até meados de 1960, quando foram substituídos por catalisadores à base de zeólitas, mais estáveis termicamente e mais seletivos ${ }^{67}$.

A pilarização de montmorilonitas a partir de 1977 permitiu produzir catalisadores baseados em montmorilonitas pilarizadas, cuja estabilidade térmica visava competir com a das zeólitas. Isso não foi atingido, pois as temperaturas desenvolvidas no processo de regeneração dos catalisadores desativados ao longo do processo de craqueamento catalítico que é atualmente utilizado (da ordem de $780{ }^{\circ} \mathrm{C}$ ) praticamente inviabilizam o uso de argilas pilarizadas, uma vez que a montmorilonita (que é o argilomineral mais utilizado na produção de argilas pilarizadas) sofre desidroxilação abaixo dessas temperaturas, fazendo com que a estrutura da argila pilarizada como um todo entre em colapso. Por outro lado, estão em curso pesquisas procurando melhorar a atividade catalítica das esmectitas pilarizadas em reações que se dêem em faixas mais baixas de temperatura, especialmente procurando tirar vantagem da seletividade devida ao fato de que as galerias entre os pilares podem acomodar moléculas maiores e/ou mais complexas (com ramificações, por ex.) do que os canais das zeólitas. Tais reações (chamadas em francês de reações de "chimie douce") são do domínio de interesse, por exemplo, da indústria farmacêutica.

Resumindo, os argilominerais 2:1 com basal expansível podem ser especialmente seletivos para forma e dimensões de moléculas adsorvidas nas galerias (por exemplo, selecionar enantiomorfos quirais). $\mathrm{O}$ fato de que esses argilominerais têm sido usados para controlar estericamente os produtos de um grande número de reações orgânicas indica a grande utilidade de seu uso na Indústria Farmacêutica e de produtos químicos especiais (Química Fina). As referências 31, 71 e 73 trazem uma lista bastante completa de reações químicas orgânicas catalisadas por argilominerais.

\section{Montmorilonitas como suportes para reagentes e catalisadores}

Recentemente houve um ressurgimento no interesse em utilizar reagentes e catalisadores suportados em sistemas químicos heterogêneos para tornar mais simples a purificação dos produtos da reação: o reagente gasto ou o catalisador é simplesmente separado por filtração. Geralmente o suporte é montmorilonita ativada por ácido, por fornecer áreas específicas elevadas. Exemplos de materiais depositados nesse suporte para catalisadores comerciais: filmes de sais inorgânicos como nitratos de cobre (nome comercial: "claycop"); de ferro ("clayfen"); cloretos de cobre, magnésio e zinco ${ }^{31}$. A "heterogenisação" do catalisador suportado em montmorilonita, de modo geral, produziu maior rendimento nas reações químicas, maior especificidade no produto formado e maior seletividade estereoquímica que o sistema homogêneo equivalente.
O interesse crescente no emprego de argilominerais ativados por ácido para uso como suportes de reagentes e catalisadores tem resultado em maior demanda por esses materiais. Por outro lado, argilominerais esmectíticos não ativados por ácidos têm se mostrado altamente eficientes no controle de reações químicas entre substâncias orgânicas, o que também provoca demanda maior por esses argilominerais.

\section{Estudos fundamentais a respeito de interações argilominerais/ compostos orgânicos}

Uma área de pesquisa extremamente ativa atualmente na Química das Argilas é a que trata de aspectos fundamentais relacionados às interações entre argilominerais, especialmente com basais expansivos (hospedeiro) e compostos orgânicos intercalados entre as camadas 2:1 expansíveis (convidado). O aumento do grau de conhecimento a respeito do que ocorre nesses sistemas permite a proposição e o desenvolvimento de novas aplicações.

Exemplos de estudos muito significativos realizados nessa área são os de Gessner e colaboradores, do Instituto de Química de São Carlos da USP, que vêm estudando os mecanismos de interação em meio aquoso entre moléculas catiônicas corantes como Azul de Metileno e Vermelho Neutro com montmorilonitas e hectoritas naturais e sintéticas. Uma excelente revisão dessas pesquisas foi publicada nesta revista ${ }^{74}$

Estudos fundamentais também têm considerado as galerias entre as camadas 2:1 como um micro-reator cujas paredes são catalisadores e cuja estrutura cristalina permite direcionar, inclusive estereoquimicamente, a natureza e proporção dos produtos da reação química. Há um número muito grande de exemplos publicados dessas "clay mediated organic reactions". Um exemplo no Brasil é o de Constantino e colaboradores ${ }^{75}$ do Instituto de Química da USP, que vêm estudando a caracterização de produtos da interação argila-porfirinas, utilizando argilas de estrutura 2:1, naturais e sintéticas, na forma sódica.

Um exemplo de estudo fundamental que pode levar a uma aplicação significativa é o da utilização de argilas esmectíticas para a obtenção de sensores eletroquímicos modificados ${ }^{76}$. Eletrodos modificados por argilas ("clay modified electrodes"- CME) têm sido aplicados na fabricação de sensores químicos. Um sensor químico é um pequeno artefato que, como resultado de uma interação química entre a substância analisada e o artefato sensor, transforma a informação química ou bioquímica de tipo qualitativo ou quantitativo em um sinal útil analiticamente. Os CME são eletrodos usados em amperometria, potenciometria ou conductimetria, recobertos com uma película contínua e sem furos de um argilomineral, geralmente montmorilonita ou hectorita naturais ou sintéticas; excepcionalmente, outros argilominerais, como nontronita e vermiculita, podem ser empregados. Esses CME podem ser utilizados em análise química, tanto de elementos como de compostos iônicos inorgânicos, orgânicos e bioquímicos. O grupo de Toma e colaboradores ${ }^{77}$ do IQ - USP vem desenvolvendo sensores nos quais são utilizadas montmorilonitas na sua fabricação.

\section{Evolução química: especulações e hipóteses}

Aparentemente há um acordo entre especialistas de que os microfósseis mais antigos encontrados nas rochas da Terra têm de 3,3 a 3,5 x $10^{9}$ anos de idade. Esses microfósseis indicam que a evolução biológica já havia começado nessa época e influenciou a evolução química do planeta através de mecanismos de realimentação ("feedback") ou, como se expressa atualmente, "spontaneous or molecular self-assembly" 78 . 
No curso da evolução química do planeta ainda pré-biológico, um número expressivo de moléculas grandes (aminoácidos, purinas, pirimidinas, ácidos graxos e açúcares) foi formado a partir dos constituintes dessa atmosfera primordial: $\mathrm{H}_{2}, \mathrm{H}_{2} \mathrm{O}, \mathrm{NH}_{3},(\mathrm{CN})_{2}, \mathrm{CO}$, $\mathrm{CO}_{2}, \mathrm{HCHO}$ e $\mathrm{H}_{2} \mathrm{~S}$. A maioria das sínteses de tais moléculas pode ter sido induzida pela ação de descargas elétricas e radiação ultravioleta proveniente do Sol.

Adsorção normal e seletiva por argilominerais pode ter acumulado grandes quantidades desses compostos, facilitando novas sínteses: com maiores concentrações, reações de polimerização dos vários tipos de compostos podem ter ocorrido e macromoléculas podem ter sido desenvolvidas, incluindo peptídios e proteínas. A organização das galerias das esmectitas e dos canais das paligorsquitas-sepiolitas poderia ter agido como micro-reatores com paredes cataliticamente ativas ${ }^{79}$. Vanádio-, níquel- e cobre-porfirinas foram encontradas em sedimentos bastante antigos e têm sendo utilizadas como marcadores geoquímicos ${ }^{80}$, o que vem de encontro às hipóteses mencionadas.

No $6^{\circ}$ Congresso Internacional da AIPEA (Associação Internacional para o Estudo das Argilas) em 1978, realizado na Universidade de Oxford, Inglaterra, o Prof. Ponnamperuma, da Universidade de Maryland, EUA, proferiu uma conferência intitulada "O Papel dos Argilominerais na Evolução Química". Nesse mesmo congresso, o Dr. H. van Damme, do CNRS, Orléans, França, apresentou um estudo sobre as interações de várias porfirinas com montmorilonita. No $13^{\circ}$ Congresso Internacional realizado em agosto de 2005 na Waseda University, Tóquio, um dos simpósios foi "Clays and Origins of Life: Self-Organization, Biomineralization, Macromolecules, Chirality". As referências 79 trazem um painel das idéias atuais do papel da montmorilonita nessas sínteses, polimerizações e formação de biomoléculas.

\section{Argilas aniônicas ou "LDHs"}

Finalizando, deve ser lembrado que as argilas e os argilominerais, naturais e sintéticos, vem sendo chamados de "argilas catiônicas" pelas estruturas cristalinas e propriedades químicas descritas em artigo anterior sobre Argilas Especiais. Hidróxidos metálicos duplos podem ser sintetizados com estruturas em camadas ("layered double hydroxides" - LDHs), geralmente do tipo da brucita, $\mathrm{Mg}(\mathrm{OH})_{2}$ cristalino. Esses hidróxidos têm espaços interlamelares, ou seja, entre as camadas 2:1 (tal como os argilominerais esmectíticos), uma deficiência de carga negativa estrutural, originária do tipo de composição química $\left[\mathrm{M}_{1-x}{ }^{2+} \mathrm{M}_{\mathrm{x}}(\mathrm{OH})_{2}\right]^{\mathrm{x+}}$, a qual é balanceada por ânions como $\mathrm{CO}_{3}{ }^{2-}$ ou $\mathrm{SO}_{4}{ }^{2-}$, trocáveis reversivelmente, intercalados. Assim, os conhecimentos científicos das propriedades físicas, químicas e das aplicações das argilas catiônicas, obviamente com as adaptações adequadas, podem ser transferidos para os LDHs que, por esse motivo, são chamados por analogia de "argilas aniônicas".

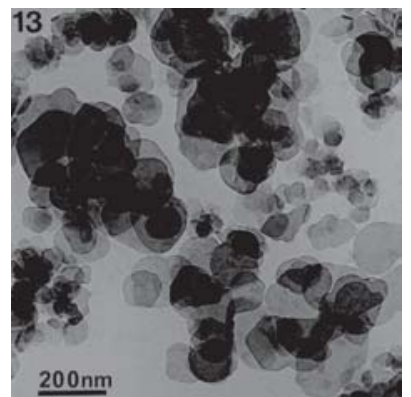

Figura 15. MET de microcristais lamelares, com perfil aproximadamente hexagonal, de hidróxido duplo de alumínio e níquel
Os LDHs sintéticos são materiais promissores devido ao grande número de aplicações industriais potenciais, por causa da grande versatilidade e facilidade de manipulação de suas propriedades em uma ampla faixa de composições químicas e de seu baixo custo. Além do grande número de estudos científicos publicados sobre suas sínteses e propriedades ${ }^{81}$, exemplos de aplicações já em uso industrial são: descontaminação de água e ar; síntese de produtos químicos intermediários e especiais; melhoria do rendimento na conversão do gás natural e em Fotoquímica; em compósitos e nanocompósitos.

Os cristais de LDHs são normalmente lamelares, com perfil hexagonal ou arredondado e com dimensões variando de micro a nanométricas, tais como os argilominerais esmectíticos. A Figura 15 é uma micrografia eletrônica de transmissão de um LDH de alumínio e níquel.

\section{CONCLUSÃO}

Durante o século XX, o processamento das argilas para fins industriais nos países economicamente desenvolvidos ampliou-se a partir de tecnologias de baixa qualidade, utilizando equipamentos baratos de operações unitárias para processos altamente sofisticados de Engenharia Química e de Química.

Neste artigo procurou-se mostrar o grande número de estudos e pesquisas sobre argilas e argilominerais que tem ocorrido nos últimos 30 anos. Esses estudos são interdisciplinares e envolvem muita ciência fundamental e diferentes tecnologias. As estruturas cristalinas dos argilominerais, as interações entre moléculas orgânicas e argilominerais, as propriedades dos diversos sistemas argilomineral-composto formados e as propriedades catalíticas dos argilominerais continuam sendo ativamente estudadas, mesmo que alguns estudos pareçam muito "acadêmicos" para aplicações imediatas. As tendências atuais de aplicação são de se empregar microcristais ("nanoclay"), materiais de áreas específicas maiores, com maior pureza e com modificação superficial dos microcristais, de forma a permitir maior especialização nas aplicações industriais e resistir à competição de outros minerais naturais e de compostos sintéticos.

\section{AGRADECIMENTOS}

À S. P. Toledo pela organização de algumas figuras.

\section{REFERÊNCIAS}

1. Clarke, G. M.; Industrial Minerals 1985, September, 25.

2. O'Driscoll, M.; Industrial Minerals 1988, July, 43.

3. Barrer, R. M.; MacLeod, D. M.; Trans. Faraday Soc. 1955, 51, 1290.

4. Jackson, N. Em Proceedings of International Workshop of Activated Clays; Volzone, C., ed.; CETMIC: La Plata, 1988, p. 1-7.

5. Brindley, G. W.; Brown, G.; Crystal Structures of Clay Minerals and their Identification, Mineralogical Society: London, 1980.

6. Newman, A. C. D.; Chemistry of Clays and Clay Minerals, Mineralogical Society: Londres, 1987 p. 1-129.

7. http://pubs.usgs.gov/of/2001/of01-041, acessada em Janeiro 2006.

8. Wilson, I. R.; Souza Santos, H.; Souza Santos, P.; Cerâmica 1998, 44, 118.

9. Souza Santos, P.; Ciência e Tecnologia de Argilas, Ed. Edgard Blücher: São Paulo, 1989, vol. I.

10. Hofstadt, C. E.; Fahn, R.; "Industrial Minerals” International Congress, $2^{\text {nd }}$ ed., München, 1976, p. 95.

11. Souza Santos, P.; Souza Santos, H.; Cerâmica 1980, 36, 127.

12. Norma Francesa NF T 30-001; Dictionnaire technique des peintures et des travaux de peinturage, citada em Grandov, P.; Pastour, P.; Peintures et Vernis, Hermann: Paris, 1969, p. 853.

13. Murray, G. T.; Introduction to Engineering Materials, Marcel Dekker: New York, 1993, p. 18.

14. Em ref. 13, p. 425 . 
15. Katz, H. S.; Milewski, J. V.; Handbook of Fillers for Plastics, Van Nostrand Reinhold: New York, 1987, p. 29.

16. Murphy, J.; Proceedings Euro-Fillers'99, Lyon, França, 1999

17. Em ref. 15 , p. 145

18. Ciminelli, R. R. Em Plásticos Carregados e Reforçados; Sousa, J. A.; Ciminelli, R. R., eds.; Associação Brasileira de Polímeros/ABPol, 1995, p. 84-89.

19. Jeffs, D. G. Em Methods for Increasing the Efficiency of Silane, Treatment of Clays, ECC Intl: Cornwall, 1979.

20. Fonseca, M. G.; Airoldi, C.; Quim Nova 2003, 26, 699.

21. Solomon, D. H.; Hawthorne, D. G.; Chemistry of Pigments and Fillers, Wiley: New York, 1991.

22. Em ref. 15, p. 216.

23. Michot, L. J.; Villiéras, F.; François, M.; Yvon, J.; Le Dred, R.; Cases, J. M.; Langmuir 1994, 10, 3765; Yvon, J.; Cases, J. M.; Villiéras, F.; Michot, L.; Thomas, F.; C.R. Academie des Sciences 2002, 334, 717.

24. Van Oss, C. J.; Giese, R. F.; Clays Clay Miner. 1995, 43, 474

25. Wu, W.; Clays Clay Miner. 2001, 49, 446.

26. Souza Santos, P.; Souza Santos, H.; Cerâmica 1991, 37, 1; Santos, C. A. X.; Souza Santos, P.; Miner. Metall. Process. 1996, 60, 33; Sciutti, S. A.; Corrêa, M. P.; Braz. J. Chem. Eng. 1998, 15, 406.

27. Gardolinski, J. E.; Peralta-Zamora, P.; Wypych, F.; J. Colloid Interface Sci. 1999, 211, 137; Gardolinski, J. E.; Ramos, L. P.; Souza, G. P.; Wypych, F.; J. Colloid Interface Sci. 2000, 221, 284.

28. Mackinnon, I. D. R. Em ref. 4, p. 55-64

29. Volzone, C.; Thompson, J. G.; Melnitchenko, A.; Ortega, J.; Palethorpe, S. R.; Clays Clay Miner. 1999, 47, 647.

30. Souza Santos, P.; Souza Santos, H. Em Book of Summaries of the $6^{\text {th }}$ International Clay Conference, Oxford, 1978; Souza Santos, P.; Souza Santos, H.; Cerâmica 1992, 38, 29.

31. McCabe, R. W. Em Inorganic Materials; Bruce, D. W.; O’Hare, D., eds.; $2^{\text {nd }}$ ed., Wiley: Chichester, 1997.

32. Grim, R. E.; Applied Clay Mineralogy, Mc-Graw-Hill: Nova York, 1962.

33. Keegan, N.; Industrial Minerals 1998, Agosto, 23; Kendall, T.; Industrial Minerals 1996, Maio, 25.

34. Díaz, F. R. R.; Souza Santos, P.; Quim Nova 2001, 24, 345

35. Fahn, R.; Fenderl, K.; Clay Miner. 1983, 18, 447.

36. Lagaly, G.; Ogawa, M.; Dérkány, I. Em Handbook of Clay Science; Bergaya, F.; Theng, B. K. G.; Lagaly, G., eds.; Elsevier: Amsterdam, 2006, p. 309-378.

37. Jordan, J. W.; J. Phys. Colloid Chem. 1949, 53, 294.

38. Laba, D.; Rheological Properties of Cosmetics and Toiletries, Marcel Dekker: New York, 1993.

39. Weiss, A.; Angew. Chem., Int. Ed. 1963, 75, 113; Weiss, A.; Clays Clay Miner. 1963, 10, 191.

40. Lagaly, G.; Solid State Ionics 1986, 22, 43; Lagaly, G. Em Proceedings of the $10^{\text {th }}$ International Clay Conference; Churchman, G. J., ed.; CSIRO Publishing: Melbourne, 1995, p. 137-144.

41. Grim, R. E.; Güven, N.; Bentonites, Elsevier: Amsterdam, 1978.

42. Quarmley, J. Em Industrial Clays; Keegan, N., ed.; $3^{\text {rd }}$ ed., Industrial Minerals Information: Surrey, 2000, p. 4-12.

43. Díaz, F. R. V.; Abreu, L. D. V.; Souza Santos, P.; Anais do $38^{\circ}$ Congresso Brasileiro de Cerâmica, 1994, vol. 1; Díaz, F. R. V.; Abreu, L. D. V.; Souza Santos, P.; Anais do $37^{\circ}$ Congresso Brasileiro de Cerâmica, 1993, vol. 2.

44. Hanna, R. A.; Vieira Coelho, A. C.; Souza Santos, P.; $5^{\text {th }}$ Intl. LatinAmerican Conf. Powder Techn., 2005, vol. 1.; Pereira, K. R. O.; Hanna, R. A.; Díaz, F. R. V.; Materials Res. 2005, 8, 77; Hanna, R. A.; Díaz, F. R. V.; Souza Santos, P.; II Encontro da Sociedade Brasileira de Pesquisa em Materiais, Rio de Janeiro, Brasil, 2003.

45. Pereira, K. R. O.; Dissertação de Mestrado, Universidade Federal de Campina Grande, Brasil, 2003; Ferreira, H. S.; Dissertação de Mestrado, Universidade Federal de Campina Grande, Brasil, 2005.

46. Vaia, R. A.; Wagner, H. D.; Materials Today 2004, 7, 32.

47. Roy, R.; Roy, D. M.; Mater. Res. Bull. 1984, 19, 169.

48. Giannelis, E. P.; Messensmith, P. B.; J. Polym. Sci., Part A: Polym. Chem. 1995, 33, 1047.
49. Kato, M.; Usuki, A. Em Polymer-Clay Nanocomposites; Pinnavaia, T. J.; Beall, G. W., eds.; Wiley: Chichester, 2000, cap. 5.

50. Schoonheydt, R. A.; Clays Clay Miner. 2002, 50, 411; Zbik, M.; Smart, R. S. C.; Clays Clay Miner. 1998, 46, 153.

51. Wagner, A.; Cooper, S.; Riedlinger, M.; Industrial Biotechnology 2005, 1, 190. 52. Alexandre, M.; Dubois, P.; Mater. Sci. Eng. 2000, $28,1$.

53. Tjong, S. C.; Meng, Y. Z.; Hay, A. S.; Chem. Mater. 2002, 14, 44; Tjong, S. C.; Meng, Y. Z.; Xu, J.; Li, R. K. Y.; Xu, Y.; Rajulu, A. V.; J. Polym. Sci., Part B: Polym. Phys. 2003, 41, 749; J. Polym. Sci., Part B: Polym. Phys. 2003, 41, 2332.

54 Vaia, R. A.; Giannelis, E. P.; MRS Bulletin 2001, Maio, 394.

55. Zanetti, M.; Lomakin, S.; Camino, G.; Macromol. Mater. Eng. 2000, 279, 1.

56. Gao, F.; Materials Today 2004, 7, 50.

57. Ahmadi, S. J.; Huang, Y. D.; Li, W.; J. Mater. Sci. 2004, 39, 1919.

58. Zeng, Q. H.; Yu, A. B.; Lu(Max), G. Q.; Paul, D. R.; Nanosci. Nanotechnol. 2005, 5, 1574 .

59. Ray, S. S.; Okamoto, M.; Prog. Polym. Sci. 2003, 28, 1539.

60. Ginzburg, V. V.; Endelman, O. V.; Manevitch, L. I.; Phys. Rev. Lett. 2001, 86,5073 .

61. Lagaly, G.; Clays Clay Miner. 1999, 15, 1.

62. Brindley, G. W.; Sempels, R. E.; Clay Miner. 1977, 12, 229.

63. Johansson, G.; Acta Chem. Scand. 1960, 14, 771.

64. Volzone, C.; Abreu, L. D. V.; Vieira Coelho, A. C.; Souza Santos, P.; Anais do $43^{\circ}$ Congresso Brasileiro de Cerâmica, 1999; Abreu, L. D. V.; Souza Santos, P.; Vieira Coelho, A. C.; Anais do $41^{\circ}$ Congresso Brasileiro de Cerâmica, 1997, vol. 1; Vieira Coelho, A. C.; Abreu, L. D. V.; Souza Santos, P.; Anais do $40^{\circ}$ Congresso Brasileiro de Cerâmica 1996, 42, 150; Vieira Coelho, A. C.; Souza Santos, P.; Emilio, C. G.; Anais do $40^{\circ}$ Congresso Brasileiro de Cerâmica, 1996, 42, 252; Abreu, L. D. V.; Vieira Coelho, A. C.; Souza Santos, P.; Anais do $39^{\circ}$ Congresso Brasileiro de Cerâmica, 1995, vol. 1.

65. Pinnavaia, T. J.; Science 1983, 220, 365.

66. Pinnavaia, T. J. Em Chemical Reactions in Organic and Inorganic Constrained Systems; Setton, R., ed.; Reidel: Nova York, 1986, cap. 6.

67. Bergaya, F. Em Matériaux Argileux: Structure, Proprietés et Applications; Decarreau, A., ed.; S. F. M. Cristalographie: Paris, 1990, p. 511.

68. Kloprogge, J. T.; J. Porous Mater. 1998, 5, 5; Ding, Z.; Kloprogge, J. T.; Frost, R. L.; J. Porous Mater. 2001, 8, 273; Kloprogge, J. T.; Duong, L. V.; Frost, R. L.; Environ. Geol. 2005, 47, 967.

69. Michot, L. J.; Pinnavaia, T. J.; Clays Clay Miner. 1991, 39, 643.

70. Schoonheydt, R. A.; Pinnavaia, T. J.; Lagaly, G.; Gangas, N.; Pure Appl. Chem. 1999, 71, 2327.

71. Vieira Coelho, A. C.; Souza Santos, P.; Rev. Bras. Eng. Quim. 1988, 11, 26; Vieira Coelho, A. C.; Souza Santos, P.; Bol. Tec. Petrobras 1988, 31, 143.

72. Luna, F. J.; Schuchardt, V.; Quim. Nova 1999, 22, 104; Pergher, S. B. C.; Corma, A.; Fornes, V.; Quim. Nova 1999, 22, 693; Aguiar, M. R. P.; Novaes, A. C.; Quim. Nova 2002, 25, 1145.

73. Clearfield, A. Em Advanced Catalysts and Nanostructured Materials; Michell, I. V., ed.; Academic Press: Nova York, 1996, cap. 14.

74. Newmann, M. G.; Gessner, F.; Cione, A. P. P.; Sartori, R. A.; Cavalheiro, C. C. S.; Quim. Nova 2000, 23, 818.

75. Constantino, V. R. L.; Barbosa, C. A. S.; Bizeto, M. A.; Dias, P. M.; An. Acad. Bras. C. 2000, 72, 45; Dias, P. M.; Faria, D. L. A.; Constantino, V. R. L.; Clays Clay Miner. 2005, 53, 362.

76. Guth, U.; Brosda, S.; Schomburg, J.; Appl. Clay Sci. 1996, 19, 229; Mousty, C.; Appl. Clay Sci. 2004, 27, 159.

77. Anaissi, F. J.; Demets, G. J. F.; Toma, H. E.; Dovidankas, S.; Vieira Coelho, A. C.; Mater. Res. Bull. 2001, 36, 289.

78. Whitesides, G. M.; Mathias, J. P.; Seto, C. T.; Science 1991, 254, 1312.

79 Hazen, R. M.; Elements 2005, 1, 135; Cody, G. D.; Elements 2005, 1, 139; Ferris, J. P.; Elements 2005, 1, 145; Smith, J. V.; Elements 2005, 1, 151; Cairns-Smith, A.; Elements 2005, 1, 157.

80. Bergaya, F.; van Damme, H.; Geochim. Cosmochim. Acta 1982, 46, 349.

81. Vaccari, A.; Appl. Clay Sci. 1996, 10, 1. 